\title{
Investor Sentiment And Close-End Country Funds?
}

Kevin C.H. Chiang, University of Vermont, USA

Craig H. Wisen, University of Alaska Fairbanks, USA

Xiyu (Thomas) Zhou, University of Alaska Fairbanks, USA

\begin{abstract}
An innovative method to estimate the duration of investor sentiment is applied to closed-end country fund returns and it finds that U.S. investor sentiment has a short life. The effects of sentiment on closed-end country fund returns are largely consistent with existing literature however, it is only apparent in daily time-series regressions. Sentiment rapidly fades at a weekly frequency and virtually disappears using monthly return observations. These results suggest that the kind of investor sentiment for country fund prices does not have a persistent component.
\end{abstract}

Keywords: Investor sentiment; close-end country fund

\section{INTRODUCTION}

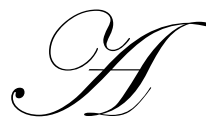

cademic and practitioner based research have often hypothesized that abnormal variations in security returns are influenced by investor sentiment. Echoing this belief, many researchers have engaged in theoretical modeling with irrational agents. Among them are Barberis, Shleifer, and Vishny (1998), Daniel, Hirshleifer, and Subrahmanyam (1998), De Long, Shleifer, Summers, and Waldmann (1990), Hong and Stein (1999), Kogan, Ross, Wang, and Westerfield (2006), and Odean (1998). Although these studies attempt to explain irregularities over various time horizons, relatively little work has been published on the persistence of investor sentiment within closed-end country funds traded in the U.S. This study explores the effects of investor sentiment on security prices in a controlled setting across various time frequencies.

A common critique of empirical investigations of investor sentiment is the joint hypothesis problem. Specifically, they are challenged by a joint test of the asset pricing model and market efficiency. Fundamental values are not normally observed in typical price setting; thus, one needs to make strong assumptions about fundamentals before addressing the impact of the joint hypothesis problem. Researchers therefore disagree on the interpretations of apparent anomalies taken from empirical findings. Fama (1998), Sadka (2006), Yogo (2006) represent one end of the spectrum and provides strong arguments favoring rationality and discount counter arguments due to model mis-specification. Other studies present empirical results on the opposite end of the spectrum which are difficult to reconcile with rational pricing; e.g., Baker and Wurgler (2006), Barberis and Shleifer (2003), Barberis, Shleifer, and Wurgler (2005), Brown and Cliff (2005), Kothari and Shanken (1997), Kumar and Lee (2006), Lamont and Thaler (2003), and Neal and Wheatley (1998). Given the possibility of model misspecification, a common attribute of the conclusions drawn from behavior-based studies is that anomalous price patterns might reflect compensation for systematic risks.

Many important questions about investor sentiment have thus far remained unanswered due to the joint hypothesis problem. Among them is whether investor sentiment is a persistent phenomenon. Related questions examine the temporal characteristics of investor sentiment and the degree to which it is economically meaningful. These questions have empirical and policy implications as well as theoretical implications that relate to underlying assumptions and model calibration.

There are at least two channels through which investor sentiment may affect security prices: (1) valuation subjectivity, and (2) arbitrage constraints. Baker and Wurgler (2006) argue that either channel could affect prices. 
Resolution is not obvious because arbitrage constraints may affect the level of investor sentiment when valuation subjectivity is present but difficult to assess. The purpose of the current study is to address these questions by examining the effects of investor sentiment on closed-end country fund prices.

A closed-end country fund is a publicly traded investment company that issues a fixed number of fund shares domestically and then uses the sale proceeds to invest in a portfolio of securities in a foreign country. Country funds have several advantages in determining the effects of investor sentiment on security prices. First, the net asset values (NAVs) of country funds are usually directly observable and are thus attractive proxies of fundamentals (Klibanoff, Lamont, and Wizman, 1998). Hardouvelis, La Porta, and Wizman (1994) and Bodurtha, Kim, and Lee (1995) note that to the extent that foreign investors are not subject to U.S. sentiment, variations in fund premiums and discounts would reflect the differential sentiment between foreign markets and the U.S. market. The joint hypothesis problem is therefore partially mitigated when examining country fund prices. While the Net Asset Value (NAV) of closed-end country funds is a good proxy of fundamentals and thus has low subjectivity in valuation, there is a remaining component of investor sentiment in country funds (Bodurtha, Kim, and Lee, 1995). It is well known that country funds, as well as other types of closed-end funds, have binding arbitrage constraints. Lee, Shleifer, and Thaler (1991) and Fuertes and Thomas (2006) suggest that arbitraging a fund premium or discount that is considered "too narrow" may be more risky than arbitraging a fund premium or discount that is considered "too wide." The examination of country funds provides a unique opportunity therefore for analyzing the role of investor sentiment on security prices through the channel of arbitrage constraints, while concurrent valuation subjectivity is controlled at a minimal level.

This study makes two contributions. First, a new empirical specification is proposed that addresses a usual specification problem in the existing empirical framework. The new specification allows for the estimation of the effect of investor sentiment on country fund prices at a daily frequency. This is in contrast to the majority of existing studies that are conducted at weekly or monthly frequencies. The extension is important because the effect of investor sentiment on security prices is known to be time-specific in other literatures; e.g., short-run event underreaction and long-run event over-reaction. It is likely that the effects of investor sentiment on country fund prices also exhibit time-specific patterns. The empirical results show that this is indeed the case. Specifically, the study finds that investor sentiment in country fund prices has a short life. Although the effect of investor sentiment is evident at daily country fund prices it decays rapidly in a linear fashion. The "half-life" of investor sentiment for country funds is approximately five days in the sense that the average amount of U.S. sentiment exposures is reduced by approximately fifty percent when time-series regressions are applied using five-day returns. Virtually no sentiment is detected when examining monthly country fund returns.

Second, the linearly decreasing decay function for investor sentiment for country fund prices suggests that this particular type of investor sentiment does not accumulate over time and therefore is not a persistent variable. Because the role of valuation subjectivity on investor sentiment is limited among closed-end country funds, the results are consistent with the view that it takes both arbitrage constraints and valuation subjectivity to create longlasting sentiment.

\section{LITERATURE REVIEW}

\section{Investor Sentiment}

Traditional asset pricing theory is based on the view that investor sentiment plays no role in determining security prices because arbitrage forces offset demand shocks in investor sentiment. An alternative theory argues that arbitrage can be risky because the mispricing being exploited may widen, rendering the potential arbitrage unattractive. De Long, Shleifer, Summers, and Waldmann (1990), Shiller (1984), Shleifer and Summers (1990), and Shleifer and Vishny (1997) note that correlated demand shocks in investor sentiment may not be fully absorbed by arbitrage forces. Barberis and Thaler (2003) and Daniel, Hirshleifer and Teoh (2002) provide a literature review on empirical results that support this alternative view.

The current study of investor sentiment is related to the clientele-based results of Barberis, Sheleifer, and Wurgler (2005), Bodurtha, Kim, and Lee (1995), Kumar and Lee (2006), and Lee, Shleifer, and Thaler (1991). This 
literature accepts that small individual investors have preferred habitats; that is, they choose to trade only a subset of all available securities. As a result securities that have a large proportion of small-investor ownership, such as small capitalization stocks and closed-end funds, are subject to the same source of demand shocks. Therefore the returns securities predominantly held by small investors should reflect both fundamental risk and changes in sentiment.

\section{Country Funds}

The literature on closed-end country funds has two main strands of analysis; fund premiums/discounts and portfolio diversification. Errunza, Senbet, and Hogan (1998) develop a theory that explains how a country fund can trade at a premium. The theory is based on barriers to international investments. In this work the premium reflects the extent to which the fund's underlying portfolio is not spanned by the U.S. market. Bonser-Neal, Brauer, Neal, and Wheatley (1990) provide empirical support for this view and find that relaxing investment restrictions leads to lower fund premiums. Patro (2005) finds that the listing of new country funds results in lower premiums for old country funds. Alternatively, Hardouvelis, La Porta, and Wizman (1994) and Bodurtha, Kim, and Lee (1995) hypothesize that variations in fund premiums/discounts reflect the differential sentiment of U.S. investors relative to foreign investors. Because the purpose of this study is to examine the effects of U.S. investor sentiment on the pricing of country funds at various time frequencies, it is most closely related to Hardouvelis, La Porta, and Wizman (1994) and Bodurtha, Kim, and Lee (1995).

The other branch in closed-end fund research concerns the potential diversification benefits from investing in country funds. Bailey and Lim (1992) and Chang, Eun, and Kolodny (1995) find that the returns on country funds co-move strongly with U.S. market returns. Using a mean-variance test, Bekaert and Urias (1996) find significant diversification benefits for U.K.-traded country funds, but not for U.S.-traded country funds. In contrast, Choi and Lee (1996) and Lee and Hong (2002) document that country fund returns are more heavily influenced by its local factor than by the U.S. factor, which implies that investing in country funds is useful for reducing portfolio risk.

\section{THE EMPIRICAL FRAMEWORK}

The existing empirical framework in the country fund literature incorporates the dual market characteristic of country funds; i.e., they are traded in the U.S., but invest elsewhere. A two-factor model, identical to or similar to the following, is frequently used to accommodate the dual characteristic:

$R_{j}^{\text {Fund }}=a_{j}+\beta_{j} R_{U S}+\gamma_{j} V_{j}+\varepsilon_{j}$

where $R_{j}^{\text {Fund }}$ is the return on the $j$ th country fund, $R_{U S}$ is the return on the U.S. market, and $V_{j}$ is the local (foreign) factor. Although the specification is intuitive it has a severe drawback. According to the mild segmentation paradigm an asset is priced as a function of world and local market risks. In the absence of the world factor in equation (1), if a country fund has a non-zero loading on the world factor, the pricing relationship would primarily be absorbed by $R_{U S}$ because of the large market weight of the U.S. market with respect to the world market portfolio. Consequently, it would be difficult to infer the effects of U.S. sentiment on fund returns through the study of $\beta_{j}$. For the present study, a new empirical specification is proposed to eliminate the drawback and includes the world factor, the U.S. sentiment variable, and the local factor.

The current study is based on the mild segmentation paradigm. This paradigm has been widely used in the literature of country funds because country funds would be redundant in a completely integrated world market whereas they would not exist if international equity markets were completely segmented. ${ }^{1}$ The study follows this convention and assumes the following two-factor return generating model of Errunza and Losq (1985):

$R_{j}^{N A V}=a_{j}^{N A V}+\beta_{j}^{N A V} R_{w}+\gamma_{j}^{N A V} V_{j}+\varepsilon_{j}^{N A V}$

${ }^{1}$ Examples include Choi and Lee (1996), Errunza, Senbet, and Hogan (1998), and Lee and Hong (2002), among others. 
where $R_{j}^{N A V}$ is the return on the NAV of the $j$ th country fund, and $R_{w}$ is the fundamental world market factor. The essence of equation (2) is that the pricing of the underlying portfolio for a country fund is determined by both world and local market risks, whereas local risk does not affect returns in other countries.

A country fund is a claim to the aggregation of the NAV and the premium or discount of the fund. Because the NAV is determined in the local market, this leaves only the fund premium to be determined in the U.S. Based on the null hypothesis that the return on fund premium is not subject to U.S. sentiment shocks, one can write the return on fund premium in the following form:

$R_{j}^{\text {Premium }}=a_{j}^{\text {Premium }}+\phi_{j}^{\text {Premium }} V_{U . S .}+\varepsilon_{j}^{\text {Premium }}$

where $R_{j}^{\text {Premium }}$ is defined as $\left(\left(1+R_{j}^{\text {Fund }}\right) /\left(1+R_{j}^{N A V}\right)\right)-1$, and $V_{U . S}$ is the U.S. sentiment variable that is orthogonal to the world factor, and $H_{0}: \phi_{j}^{\text {Premium }}=0$. Note that the definition of $R_{j}^{\text {Premium }}$ reflects the fact that the fund premium is simply an accounting relationship for the exchange of the fund and the underlying portfolio.

The study aggregates equations (2) and (3) and uses the a first-order approximation to obtain the pricing relationship for the fund:

$R_{j}^{\text {Fund }}=a_{j}^{\text {Fund }}+\beta_{j}^{N A V} R_{w}+\gamma_{j}^{N A V} V_{j}+\phi_{j}^{\text {Premium }} V_{U . S .}+\varepsilon_{j}^{\text {Fund }}$

This equation reflects that the returns of the fund are likely to be driven by three variables: the world factor, the local factor, and the U.S. sentiment factor. The local variable is included because the fund holdings are traded in the local market, and the U.S. sentiment variable is included because the fund premium may be affected by changes in U.S. sentiment. One of the strengths of the specification is that, after accounting for the world market risk of the fund, the specification in equation (4) measures the relative impacts of local factor and U.S. sentiment on fund share prices in a symmetrical manner. The use of the orthogonal regression residuals of local security returns and U.S. security returns against world returns to proxy for the local factor and the U.S. sentiment variable, respectively, would not lead to a potential spurious relationship between fund returns and the U.S. sentiment variable because of the large market capitalization of the U.S. market. The specification also enables econometricians to study country funds in a richer data setting in the sense that equation (4) does not require observations on fund premiums. Many existing studies rely on weekly NAV observations that are usually disclosed on weekends. A few funds (e.g., the Mexico Fund, the India Fund, and the Taiwan Fund) do not report their NAVs on weekends and this increases the complexity of non-synchronous analysis. Through the avoidance of these data problems, the proposed specification enables one to study country funds in a broader data setting because fund returns are available at daily and lower frequencies from the Center for Research in Security Prices (CRSP) database.

The current approach and the clientele-based specification of Bodurtha, Kim, and Lee (1995) are empirical. It is thus necessary to compare equations (2) and (3) with the pricing relationships in equations (2a) and (2b) of Bodurtha, Kim, and Lee (1995, p.888). ${ }^{2}$ One finds that equations (2) and (2a) are similar, whereas equations (3) and (2b) are different. Bodurtha, Kim, and Lee state in their equation (2b) that the pricing of fund shares (using our notation) can be explained in the following relationship: ${ }^{3}$

$R_{j}^{\text {Fund }}=a_{j}^{\text {Fund }}+\beta_{j}^{\text {Fund }} R_{j w}+\phi_{j}^{\text {Fund }} V_{U . S .}+\varepsilon_{j}^{\text {Fund }}$

That is, under the usual first-order approximation, one would obtain the following pricing relationship:

$R_{j}^{N A V}+R_{j}^{\text {Premium }}=a_{j}^{\text {Fund }}+\beta_{j}^{\text {Fund }} R_{j w}+\phi_{j}^{\text {Fund }} V_{U . S .}+\varepsilon_{j}^{\text {Fund }}$

\footnotetext{
${ }^{2}$ The equations (2a) and (2b) of Bodurtha, Kim, and Lee (1995) are $R_{j t}{ }^{N A V}=\alpha_{j}^{N A V}+\beta_{j} \mathrm{f}_{j t}+\gamma_{j}^{N A V} s_{j t}{ }^{N A V}+\varepsilon_{j t}{ }^{N A V}(2 \mathrm{a})$ and $R_{j t}{ }^{S P}=\alpha_{j}^{S P}$ $+\beta_{j} \mathrm{f}_{j t}+\gamma_{j}^{S P} s_{j}^{S P}+\varepsilon_{j t}^{S P}(2 \mathrm{~b})$ where SP stands for stock price of the fund, $\mathrm{f}_{j t}$ is the fundamental risk factor for the local market, $s_{j t}{ }^{N A V}$ is the foreign market demand in country $j$, and $s_{j}^{S P}$ is the U.S. market demand (sentiment).

${ }^{3}$ The authors use the $j$ subscript on $R_{j w}$ to reflect market segmentation.
} 
By moving $R_{j}^{\text {Premium }}$ to the right side of the equation and recognizing that $R_{j}^{\text {Premium }}$ is not a function of the local factor because fund shares are traded in the U.S., one would obtain the following pricing relationship:

$R_{j}^{N A V}=a_{j}^{\text {Fund }}+\beta_{j}^{\text {Fund }} R_{j w}+\phi_{j}^{\text {Fund }} V_{U . S .}-f\left(V_{U . S}\right)+\varepsilon_{j}^{\text {Fund }}$

where the general function $f\left(V_{U . S}\right)=R_{j}^{\text {Premium }}$ is used to highlight the fact that the return on fund premium is not related to the local factor. As a result, equation (7) and, thus, equation (2b) of Bodurtha, Kim, and Lee (1995), implies that the pricing of the NAV is not a function of the local factor. However, this is a contradiction of equation (2) and the authors' equation (2b) in which the two equations relate the pricing of the NAV to the local factor. A natural consequence of the contradiction is that the authors' equations (2a) and (2b) cannot both be true. ${ }^{4}$

\section{DATA}

Daily and monthly country fund returns are retrieved from the 2001 CRSP database. The ending period of the sample is December 31,2000. The study excludes country funds whose first available daily returns are later than January 1, 1993. The study also excludes the first two years' fund return observations from the analysis to mitigate IPO effects. ${ }^{5}$ World returns are proxied by Morgan Stanley Capital International (MSCI) World Index. The U.S. investor sentiment variable is proxied by (1) orthogonal regression residuals of S\&P 500 returns against MSCI world returns and (2) orthogonal regression residuals of NYSE smallest decile returns against MSCI world returns. The use of the latter proxy is motivated by the documented association between country fund premiums and U.S. small stocks (Bodurtha, Kim, and Lee (1995)). The local factor is proxied by orthogonal regression residuals of local market returns against MSCI world returns. D and monthly U.S. dollar returns of local markets are obtained from MSCI. This leads to a sample of 31 country funds: 11 are developed market country funds, and 21 are emerging market country funds.

Table I presents summary statistics of the sample. Except for the Singapore Fund, the Brazil Fund, and the Mexico Fund, the CRSP has return observations for sample country funds almost immediately after their IPO dates. The realized returns on sample country funds vary considerably over an average 10-year sample period. The Indonesia Fund has an annualized return of $-9.87 \%$, whereas the Mexico Fund has an annualized return of 22.92\%. The annualized standard deviations of sample country funds range from $21.24 \%$ to $49.97 \%$. The standard deviations of emerging market country funds are generally higher than the standard deviations of developed market country funds.

\section{EMPIRICAL RESULTS}

To correct for the effect of non-synchronous trading, this study follows Scholes and Williams (1977) and Dimson (1979) and augments equation (4) to include leading and lagging explanatory variables.

Table II reports the results of daily time-series regressions on country fund returns using world market returns, orthogonal local returns, and U.S. orthogonal returns. Consistent with Hardouvelis, La Porta, and Wizman (1994) and Bodurtha, Kim, and Lee (1995), this study finds that the concurrent U.S. investor sentiment exposures are all statistically significant at the $1 \%$ level for the sample of 11 developed market country funds. The NeweyWest (1987) adjusted $t$-statistics range from 2.98 to 8.70. Among the sample of 20 emerging market country funds, 10 have statistically significant exposures to the concurrent U.S. sentiment variable at the $1 \%$ level and 7 have statistically significant exposures to the concurrent U.S. sentiment variable at the $5 \%$ level.

Concurrent local factors also have substantial impacts on country fund returns. The adjusted $t$-statistics range from 4.69 to 27.66 and 31 and are statistically significant at the $1 \%$ level for the 31 sample funds. The concurrent betas with respect to MSCI world returns range from 0.58 for the Chile Fund to 1.65 for the Japan OTC Fund. The adjusted $t$-statistics range from 6.74 to 24.09 and are all statistically significant at the $1 \%$ level. The

\footnotetext{
${ }^{4}$ Another way to see the contradiction is to note that if $R_{j}^{N A V}$ is a function of the local factor and $R_{j}^{N A V}$ is a component of fund returns, fund returns must be a function of the local factor.

${ }^{5}$ We also repeat our analysis with the first two years' fund return observations. The results are similar.
} 
inclusion of leading and lagged explanatory variables has little impact on the overall results as evidenced by their low level of statistical significance. This inclusion is repeated in subsequent analyses throughout the paper without the non-synchronous adjustment. The results are robust regardless of whether this inclusion is adopted.

This study aggregates five daily returns into weekly returns and performs the same time-series regressions using weekly observations. The weekly regression results are reported in Table III. The concurrent market betas remain statistically significant at the $1 \%$ level and are consistent with the results that were produced using daily data. The adjusted $t$-statistics range from 6.08 to 19.08 . Concurrent local factors also retain their statistical significance at the $1 \%$ level. The adjusted $t$-statistics range from 4.05 to 22.49 . The overall effects of world and local factors on country fund returns are invariant to the decrease in data frequency based on the levels of adjusted $t$-statistics. In contrast, the statistical significance of the U.S. investor sentiment variable in describing country fund returns largely disappears when weekly observations are used. Except in the case of the France Growth Fund, the Germany Fund, and the Japan Equity Fund, 8 of the 11 developed market country funds lose their statistical significance to the concurrent U.S. sentiment variable. Among the 20 emerging market country funds, only the Brazil Fund, Chile Fund, and Taiwan Fund show statistically significant exposures to the concurrent U.S. investor sentiment variable at the $5 \%$ level.

These results differ from those documented by Hardouvelis, La Porta, and Wizman (1994) and Bodurtha, Kim, and Lee (1995) in which concurrent U.S. investor sentiment proxies are shown to be statistically significant variables in describing country fund returns at weekly frequency. The results from the current study imply that most of the high-frequency effects of the U.S. investor sentiment variable on country fund returns largely cancel out within a week. This is consistent with the hypothesis that U.S. demand shocks in country funds are not systematic at lower frequencies.

Given the results that U.S. investor sentiment fades at weekly frequency, one would expect a further reduction in the effects of the U.S. investor sentiment variable on country fund prices at monthly frequency. This expectation is verified in Table IV. None of the 11 developed market country funds yields statistically significant exposures to the concurrent U.S. investor sentiment variable in a monthly setting. These estimates center on zero and have a range from -0.38 to 0.57 and their adjusted $t$-statistics range from -1.13 to 1.08 . Among the 20 emerging market country funds, only the ROC Taiwan Fund yields a statistically significant estimate to the concurrent U.S. investor sentiment variable at the 5\% level. Because weekly returns of the ROC Taiwan Fund lack a statistical significance associated with the concurrent U.S. investor sentiment variable, the statistically significant result documented at the monthly level does not seem to be the result of persistent sentiment. Meanwhile, the explanatory ability of concurrent world and local risks holds up well. The adjusted $t$-statistics for the concurrent betas of the 31 sample funds range from 3.74 to 13.80 . They are all statistically significant at the $1 \%$ level. The adjusted $t$-statistics for the concurrent local factor range from 2.54 to 15.27 . The comparison of daily, weekly and monthly results suggests that the effects of the U.S. investor sentiment variable on country fund returns are rather short-lived.

To further illustrate the benefit of using daily return data for studying the impact of investor sentiment on country fund prices, daily return data is aggregated to create 12-day returns. The augmented regressions of equation (4) are repeated for these aggregated returns. Figure 1 depicts the mean, 25 percentile, and 75 percentile of concurrent U.S. investor sentiment exposures as the data frequency decreases. As the figure clearly shows, the decay function appears linear; the sentiment in country fund returns does not accumulate over time. The average value of concurrent U.S. investor sentiment exposures decreases by approximately $50 \%$ after five days. When 10 day returns are used the average value of concurrent U.S. investor sentiment exposures is virtually zero. The result suggests that investor sentiment for country fund returns does not have a persistent component.

The study has thus far documented that the U.S. investor sentiment variable is important at high frequency. To further relate the sentiment proxy to small investor sentiment, according to Lee, Shleifer, and Thaler (1991), it is necessary to establish an association between country fund returns and U.S. small stock returns because U.S. small stocks are known to be subject to small investor sentiment. In the framework of equation (4) this would mean that if U.S. small investor sentiment affects country fund returns, orthogonal regression residuals of NYSE smallest decile returns against MSCI world returns would be sharper than orthogonal regression residuals of S\&P 500 returns against MSCI world returns in describing country fund returns. 
Tables V through VII report test results using the smallest decile of NYSE returns. The daily regression results shown in Table V confirm that the concurrent U.S. exposures documented in Table II are indeed related to small investor sentiment. Except for the India Growth Fund, the $R^{2}$ values in Table V are all higher than their counterparts in Table II. In addition, except for the India Growth Fund, the concurrent U.S. investor sentiment exposures for the remaining 30 country funds are statistically significant at the 5\% level. In Table II, there are three country funds whose concurrent U.S. investor sentiment exposures are not statistically significant at the 5\% level. This sharper evidence is consistent with notion that small investors have preferred habitats in that investor sentiment drives both U.S. small stock returns and country fund returns. The concurrent world factor and local factor continue to be important explanatory variables in describing country fund returns. These estimates are all statistically significant at the $1 \%$ level.

Table VI reports weekly regression results with the use of NYSE smallest decile returns. Orthogonal regression residuals of NYSE smallest decile returns are still sharper than orthogonal regression residuals of S\&P 500 returns in describing country fund returns, but this empirical superiority is considerably reduced as data frequency decreases. Of the $31 R^{2}$ values in Table VI, 26 (five) are higher (lower) than their counterparts in Table III. Eleven of the 31 country funds show statistically significant exposures to the concurrent U.S. investor sentiment variable: five at the $1 \%$ level and six at the $5 \%$ level. Compared with the daily regression results in Table V, these weekly results suggest that there is an element of U.S. investor sentiment in country fund prices at a daily frequency. This effect diminishes at a weekly frequency. Meanwhile, concurrent world factor and local factor remain important explanatory variables in describing weekly returns. These estimates are all statistically significant at the $1 \%$ level.

Whereas the use of NYSE smallest decile returns improve the statistical significance for the U.S. investor sentiment variable at daily and weekly frequencies, the effect of U.S. investor sentiment on country fund returns disappears at monthly frequency. Of the $31 R^{2}$ values in Table VII, 15 (16) are higher (lower) than their counterparts in Table IV. None of the 11 developed market country funds shows statistical significance to the concurrent U.S. investor sentiment variable. Among the 21 emerging market country funds, the ROC Taiwan Fund is the only example showing statistical significance at the 5\% level with respect to the concurrent U.S. investor sentiment variable. The results confirm that the effects of U.S. sentiment on country fund returns cancel out at low frequencies.

This study demonstrates that there is a component of U.S. investor sentiment in country fund returns and is largely consistent with Hardouvelis, La Porta, and Wizman (1994) and Bodurtha, Kim, and Lee (1995). These results show that the effects of U.S. investor sentiment on country fund returns are rather short-lived and are only apparent with the use of daily country fund returns. They fade quickly at weekly frequency and virtually disappear when monthly return observations are used. The linearly decreasing decay function in Figure 1 suggests that investor sentiment for country fund prices does not accumulate over time.

It is possible that exchange rate risk may influence the results of the present analysis given the welldocumented result that exchange rate risk is priced in international equity markets (Chan, Karolyi, and Stulz (1992), and Dumas and Solnik (1995)). To evaluate this possibility the percentage change of exchange rates is included in the regression specification. ${ }^{6}$ To make the presentation more concise, Table VIII summarizes daily and monthly regression results for the five developed market country funds that show statistical significance for the concurrent U.S. investor sentiment variable in Table VI; i.e., the France Growth Fund, Germany Fund, Japan Equity Fund, New Germany Fund, and Swiss Helvetia Fund. Table IX summarizes daily and monthly regression results for the four emerging market country funds that show statistical significance for the concurrent U.S. investor sentiment variable in Table VI; i.e., the Brazil Fund, Chile Fund, Mexico Fund, and Thai Fund.

The results indicate that exchange rate risk is priced in country fund prices. This is consistent with previous literature. Eight out of the nine sample country funds show statistically significance exposures at the $1 \%$ level to the percentage changes of exchange rate at daily frequency. Two out of the nine sample funds yield statistically significant exposures to the percentage changes of exchange rate at monthly frequency. The addition of the exchange rate risk, however, makes little impact on the general conclusion: U.S. investor sentiment in country

${ }^{6}$ Daily percentage changes of exchange rates are inferred from daily U.S. dollar returns and daily local currency returns. 
fund returns matters only at high frequency. None of the nine sample funds have statistically significant exposures to the concurrent U.S. investor sentiment variable at monthly frequency.

\section{CONCLUSIONS}

Closed-end country funds provide an attractive research topic where excellent measures of fundamentals are directly observable. By using this property and a new empirical specification, this study examines the effects of U.S. investor sentiment on country fund returns at daily, weekly, and monthly frequencies. The results show that there is a component of U.S. investor sentiment in country fund returns which is consistent with the existing literature. The study finds, however, that this component exists only at high frequency. Once monthly return observations are used, the effects of U.S. investor sentiment virtually disappear. The evidence suggests that U.S. investor sentiment in country funds is short-lived. The "half-life" of investor sentiment in country fund prices is about five days since the average amount of U.S. investor sentiment exposure is reduced by approximately one-half when time-series regressions are applied using weekly returns.

This study is an exploration of the time-series properties of investor sentiment. The inquiry is important because it has direct implications on arbitrage costs as well as on the limitation and degree of market efficiency. Although the observability of NAVs mitigates the inherent difficulty in testing the joint hypotheses of an asset pricing model and market efficiency, this appealing property limits the scope of the results. One should note that many risky securities are imprecisely priced. To the extent that pricing difficulties may introduce and nurture investor sentiment, one would expect investor sentiment in these risky securities to be longer lived than the estimates from the present study. In contrast, the empirical estimate of the speed of the mean-reverting process in investor sentiment among closed-end country funds suggests that this is not likely to be the case.

\section{ACKNOWLEDGEMENT}

The author thanks John Jiang for his helpful comments and Kirill Kozhevnikov for his able research assistance. This research was initiated when Kevin Chiang was an assistant professor at University of Alaska Fairbanks, and he would like to acknowledge the database support from that university.

\section{AUTHOR INFORMATION}

Kevin C. H. Chiang, PhD is currently an Associate Professor of Real Estate/Finance at the University of Vermont (UVM) School of Business Administration. He had worked for Northern Arizona University and University of Alaska Fairbanks before he joined UVM. He got his PhD in Finance from Louisiana State University. His research interests include real estate investment trusts, real estate investments, sustainable real estate, and portfolio management. He has published more than 30 academic papers, and many of them are published in prestigious real estate and finance journals.

Craig Wisen, CFA, PhD is currently an Associate Professor of Finance at the University of Alaska Fairbanks (UAF) School of Management. He has worked for UAF since being awarded a PhD in Finance from the Kelly School of Business at Indiana University in 2002. His research interests are related to performance evaluation of real estate and mutual funds. He has published articles in Real Estate Economics, Journal of Investing, and Applied Financial Economics.

Xiyu (Thomas) Zhou, $\mathrm{PhD}$ is currently an Associate Professor of Finance at the University of Alaska Fairbanks (UAF) School of Management. He has worked for UAF since 2003. He was awarded a PhD in Finance degree from the Kenan-Flagler Business School at the University of North Carolina in 2004. His research works are published on Journal of Investing, Accounting and Finance, among others. 


\section{REFERENCES}

1. Bailey, W., and J. Lim, 1992, Evaluating the diversification benefits of new country funds, Journal of Portfolio Management 18, 74-80.

2. Baker, M., and J. Wurgler, 2006, Investor sentiment and the cross-section of stock returns, Journal of Finance 61, 1645-1680.

3. Barberis, N., and A. Shleifer, 2003, Style investing, Journal of Financial Economics 68,161-199.

4. Barberis, N., A. Shleifer, and R. Vishny, 1998, A model of investor sentiment, Journal of Financial Economics 40, 307-343.

5. Barberis, N., A. Shleifer, and J. Wurgler, 2005, Comovement, Journal of Financial Economics 75, 283318.

6. Barberis, N., and R. Thaler, 2003, A survey of behavioral finance, in G.M. Constantinides, M. Harris, and R. Stulz, eds.: Handbook of the Economics of Finance (Elsevier Science B.V).

7. Bekaert, G., and M.S. Urias, 1996, Diversification, integration and emerging market closed-end funds, Journal of Finance 51, 835-869.

8. Bodurtha, J.N., Jr., D. Kim, and C. Lee, 1995, Closed-end country funds and U.S. market sentiment, Review of Financial Studies 8, 879-918.

9. Bonser-Neal, C., G. Brauer, R. Neal, and S. Wheatley, 1990, International investment restrictions and closed-end country fund prices, Journal of Finance 45, 523-547.

10. Brown, G., and M. Cliff, 2005, Investor sentiment and asset valuation, Journal of Business 78, 405-440.

11. Chan, K.C., G. A. Karolyi, and R.M. Stulz, 1992, Global financial markets and the risk premium on U.S. equity, Journal of Financial Economics 32, 137-167.

12. Chang, E., C.S. Eun, and R. Kolodny, 1995, International diversification through closed-end country funds, Journal of Banking and Finance 19, 1237-1263.

13. Choi, J., and I. Lee, 1996, Market segmentation and the valuation of closed-end country funds: An empirical analysis, Review of Quantitative Finance and Accounting 7, 45-63.

14. Daniel, K., D. Hirshleifer, and A. Subrahmanyam, 1998, Investor psychology and security market underand overreactions, Journal of Finance 53, 1839-1885.

15. Daniel, K., D. Hirshleifer, and S.H. Teoh, 2002, Investor psychology in capital markets: Evidence and policy implications, Journal of monetary Economics 49, 139-209.

16. De Long, J.B., A. Shleifer, L.H. Summers, and R.J. Waldmann, 1990, Noise trader risk in financial markets, Journal of Political Economy 98, 703-738.

17. Dimson, E., 1979, Risk measurement when shares are subject to infrequent trading, Journal of Financial Economics 7, 197-226.

18. Dumas, B., and B. Solnik, 1995, The world price of foreign exchange risk, Journal of Finance 50, 445-479.

19. Errunza, V., and E. Losq, 1985, International asset pricing under mild segmentation: Theory and test, Journal of Finance 40, 105-124.

20. Errunza, V., L.W. Senbet, and K. Hogan, 1998, The pricing of country funds from emerging markets: Theory and evidence, International Journal of Theoretical and Applied Finance 1, 111-143.

21. Fama, E.F., 1998, Market efficiency, long-term returns, and behavioral finance, Journal of Financial Economics 49, 283-306.

22. Fuertes, A., and D. Thomas, 2006, Large market shocks and abnormal closed-end-fund price behaviour, Journal of Banking and Finance 30, 2517-2535.

23. Hardouvelis, G.A., R. La Porta, and T.A. Wizman, 1994, What moves the discount on country equity funds? in Jeffrey Frankel, ed.: The International of Equity Markets (University of Chicago Press, Chicago, Ill.).

24. Hong, H., and J. Stein, 1999, A united theory of underreaction, momentum trading, and overreaction in asset markets, Journal of Finance 54, 2143-2184.

25. Klibanoff, P., O. Lamont, and T.A. Wizman, 1998, Investor reaction to salient news in closed-end country funds, Journal of Finance 53, 673-699.

26. Kogan, L., S. Ross, J. Wang, and M. Westerfield, 2006, The price impact and survival of irrational traders, Journal of Finance 61, 195-229.

27. Kothari, S.P., and J. Shanken, 1997, Book-to-market, dividend yield, and expected market returns: A timeseries analysis, Journal of Financial Economics 44, 169-203. 
28. Kumar, A., and C. Lee, 2006, Retail investor sentiment and return comovements, Journal of Finance 61, 2451-2486.

29. Lamont, O., and R. Thaler, 2003, Can the market add and subtract? Mispricing and tech stock carve-outs, Journal of Political Economy 111, 227-268.

30. Lee, B., and G. Hong, 2002, On the dual characteristics of closed-end country funds, Journal of International Money and Finance 21, 589-618.

31. Lee, C., A. Shleifer, and R.H. Thaler, 1991, Investor sentiment and the closed-end fund puzzle, Journal of Finance 46, 75-109.

32. Neal, R., and S. Wheatley, 1998, Do measures of investor sentiment predict stock returns? Journal of Financial and Quantitative Analysis 34, 523-547,

33. Newey, W.K., and K.D. West, 1987, A simple, positive semi-definite, heteroskedasticity and autocorrelation consistent covariance matrix, Econometrica 55, 703-708.

34. Odean, T., 1998, Volume, volatility, price, and profit when all traders are above average, Journal of Finance 53, 1887-1934.

35. Patro, D.K., 2005, Stock market liberalization and emerging market country fund premiums, Journal of Business 78, 135-168.

36. Sadka, R., 2006, Momentum and post-earnings-announcement drift anomalies: The role of liquidity risk, Journal of Financial Economics 80, 309-349.

37. Scholes, M., and J. Williams, 1977, Estimating betas from nonsynchronous data, Journal of Financial Economics 5, 309-327.

38. Shiller, R., 1984, Stock prices and social dynamics, Brookings Papers on Economic Activity 2, 457-510.

39. Shleifer, A., and L. Summers, 1990, The noise trader approach to finance, Journal of Economic Perspectives 4, 19-33.

40. Shleifer, A., and R. Vishny, 1997, The limits of arbitrage, Journal of Finance 52, 35-55.

41. Yogo, M., 2006, A consumption-based explanation of expected stock returns, Journal of Finance 61, 539580. 
Table I: Sample of Country Funds

\begin{tabular}{|c|c|c|c|c|}
\hline $\begin{array}{c}\text { Fund Name } \\
\text { (Ticker) }\end{array}$ & IPO Date & $\begin{array}{c}\text { Date of First Return } \\
\text { Observation }\end{array}$ & $\begin{array}{l}\text { Annualized } \\
\text { Return }(\%) \\
\end{array}$ & $\begin{array}{c}\text { Annualized } \\
\text { Std. Dev. (\%) } \\
\end{array}$ \\
\hline \multicolumn{5}{|l|}{ Panel A. Developed Markets } \\
\hline Austria Fund (OST) & $09 / 21 / 89$ & $09 / 25 / 89$ & 8.08 & 31.35 \\
\hline First Australia Fund (IAF) & $12 / 12 / 85$ & $12 / 17 / 85$ & 8.41 & 30.09 \\
\hline France Growth Fund (FRF) & 05/10/90 & $05 / 14 / 90$ & 15.43 & 23.05 \\
\hline Germany Fund (GER) & $07 / 18 / 86$ & $07 / 21 / 86$ & 14.11 & 32.29 \\
\hline Italy Fund (ITA) & $02 / 26 / 86$ & $02 / 27 / 86$ & 13.72 & 35.53 \\
\hline Japan Equity Fund (JEQ) & 03/14/90 & $08 / 17 / 92$ & -1.06 & 34.41 \\
\hline Japan OTC Equity Fund (JOF) & $03 / 14 / 90$ & $03 / 15 / 90$ & 0.82 & 36.85 \\
\hline New Germany Fund (GF) & $01 / 24 / 90$ & $01 / 26 / 90$ & 9.34 & 22.22 \\
\hline Singapore Fund (SGF) & $06 / 18 / 87$ & $07 / 26 / 90$ & 5.49 & 36.63 \\
\hline Spain Fund (SNF) & $06 / 21 / 88$ & $06 / 22 / 88$ & 15.32 & 42.04 \\
\hline Swiss Helvetia Fund (SWZ) & $08 / 19 / 87$ & $08 / 20 / 87$ & 13.91 & 21.24 \\
\hline \multicolumn{5}{|l|}{ Panel B. Emerging Markets } \\
\hline Argentina Fund (AF) & $10 / 12 / 91$ & $10 / 14 / 91$ & 9.37 & 34.69 \\
\hline Brazil Fund (BZF) & $03 / 31 / 88$ & $04 / 04 / 88$ & 21.44 & 42.18 \\
\hline Brazilian Equity Fund (BZL) & $04 / 05 / 92$ & $04 / 06 / 92$ & 10.52 & 41.94 \\
\hline Chile Fund $(\mathrm{CH})$ & $09 / 27 / 89$ & $09 / 27 / 89$ & 17.87 & 34.78 \\
\hline China Fund (CHN) & 07/10/92 & $07 / 13 / 92$ & -4.32 & 40.17 \\
\hline First Philippine Fund (FPF) & $11 / 08 / 89$ & $11 / 09 / 89$ & 4.85 & 39.51 \\
\hline Greater China Fund $(\mathrm{GCH})$ & $07 / 15 / 92$ & $07 / 16 / 92$ & -1.28 & 44.25 \\
\hline India Growth Fund (IGF) & $08 / 12 / 88$ & $08 / 15 / 88$ & -4.99 & 35.70 \\
\hline Indonesia Fund (IF) & 03/01/90 & $03 / 02 / 90$ & -9.87 & 45.82 \\
\hline Jardine Fleming China (JFC) & $07 / 16 / 92$ & $07 / 17 / 92$ & -8.39 & 42.24 \\
\hline Korea Fund (KF) & $08 / 22 / 84$ & $08 / 23 / 84$ & 5.48 & 42.49 \\
\hline Korean Investment Fund (KIF) & $02 / 17 / 92$ & $02 / 18 / 92$ & 1.07 & 45.14 \\
\hline Malaysia Fund (MF) & $05 / 08 / 87$ & $05 / 11 / 87$ & 10.47 & 48.83 \\
\hline Mexico Equity \& Income (MXE) & $08 / 14 / 90$ & $08 / 16 / 90$ & 15.10 & 37.91 \\
\hline Mexico Fund (MXF) & 06/03/81 & $06 / 09 / 81$ & 22.92 & 41.12 \\
\hline ROC Taiwan Fund (ROC) & $05 / 12 / 89$ & $05 / 15 / 89$ & 3.93 & 35.34 \\
\hline Taiwan Fund (TWN) & $12 / 16 / 86$ & $12 / 17 / 86$ & 8.87 & 41.50 \\
\hline Thai Capital Fund (TC) & $05 / 22 / 90$ & $05 / 24 / 90$ & -2.77 & 49.23 \\
\hline Thai Fund (TTF) & $02 / 17 / 88$ & $02 / 18 / 88$ & 3.42 & 49.97 \\
\hline Turkish Investment Fund (TKF) & $12 / 05 / 89$ & $12 / 06 / 89$ & 16.67 & 48.80 \\
\hline
\end{tabular}


Table II: Daily Regressions

This table reports regression results based on the following specification:

$$
R_{t}^{\text {Fund }}=a^{\text {Fund }}+\sum_{-1}^{+1} \beta_{i} R_{w, t+i}+\sum_{-1}^{+1} \gamma_{i} V_{j, t+i}+\sum_{-1}^{+1} \phi_{i} V_{U . S ., t+i}+\varepsilon_{t}
$$

where $R_{t}^{\text {Fund }}$ is the daily return on the country fund invested in country $j, R_{w}$ is the daily return on the world market, $V_{j}$ is the daily orthogonal local return, and $V_{U . S}$ is the daily orthogonal U.S. return. Newey-West (1987) adjusted $t$-statistics are reported in the second row for each country fund.

\begin{tabular}{|c|c|c|c|c|c|c|c|c|c|c|c|}
\hline \multirow{2}{*}{\multicolumn{2}{|c|}{$a^{\text {Fund }}$}} & \multicolumn{3}{|c|}{$\beta$} & \multicolumn{3}{|c|}{$\gamma$} & \multicolumn{3}{|c|}{$\phi$} & \multirow{2}{*}{$\begin{array}{c}R^{2} \\
(\%)\end{array}$} \\
\hline & & $t-1$ & $t$ & $t+1$ & $t-1$ & $t$ & $t+1$ & $t-1$ & $t$ & $t+1$ & \\
\hline \multicolumn{12}{|c|}{ Panel A. Developed Markets } \\
\hline Austria & -0.00 & 0.02 & 0.81 & 0.05 & 0.11 & 0.22 & 0.11 & 0.04 & 0.25 & -0.06 & 13.43 \\
\hline$t$-stat & -0.03 & 0.47 & $11.88^{*}$ & 0.85 & $2.48 \dagger$ & $4.69 *$ & $2.70 *$ & 0.51 & $3.20 *$ & -1.00 & \\
\hline Australia & 0.00 & -0.04 & 0.67 & 0.08 & 0.10 & 0.35 & 0.06 & -0.09 & 0.43 & -0.06 & 16.91 \\
\hline$t$-stat & 0.50 & -0.94 & $10.35^{*}$ & 1.56 & $3.15^{*}$ & $10.49 *$ & 1.84 & -1.31 & $6.14 *$ & -1.07 & \\
\hline France G. & 0.00 & -0.03 & 1.11 & 0.07 & 0.17 & 0.64 & 0.05 & -0.09 & 0.56 & -0.11 & 37.28 \\
\hline$t$-stat & 0.99 & -0.59 & $20.37 *$ & 1.72 & $5.10^{*}$ & $17.26^{*}$ & 1.51 & -1.60 & $8.70^{*}$ & -1.80 & \\
\hline Germany & 0.00 & 0.01 & 0.95 & 0.01 & 0.16 & 0.32 & 0.19 & -0.19 & 0.51 & 0.04 & 17.33 \\
\hline$t$-stat & 0.98 & 0.20 & $13.70 *$ & 0.20 & $3.37 *$ & $4.84 *$ & $3.04 *$ & $-2.17 \dagger$ & $5.97 *$ & 0.60 & \\
\hline Italy & 0.00 & 0.05 & 0.76 & 0.04 & 0.09 & 0.35 & -0.00 & 0.05 & 0.28 & -0.13 & 16.72 \\
\hline$t$-stat & 1.14 & 1.06 & $11.56^{*}$ & 0.71 & $2.82 *$ & $11.79 *$ & -0.01 & 0.90 & $4.37 *$ & $-1.97 \dagger$ & \\
\hline Japan E. & -0.00 & -0.26 & 1.44 & -0.03 & 0.03 & 0.52 & 0.12 & -0.20 & 0.47 & 0.10 & 28.07 \\
\hline$t$-stat & -1.28 & $-3.26^{*}$ & $12.71 *$ & -0.28 & 0.54 & $8.83 *$ & 1.84 & -1.67 & $3.53 *$ & 0.86 & \\
\hline Japan OTC & -0.00 & -0.29 & 1.65 & 0.12 & -0.04 & 0.64 & 0.14 & -0.23 & 0.78 & 0.12 & 26.72 \\
\hline$t$-stat & -0.97 & $-4.09 *$ & $18.29 *$ & 1.45 & -0.81 & $8.36^{*}$ & $2.33 \dagger$ & $-2.07 \dagger$ & $5.85^{*}$ & 0.92 & \\
\hline N. Germany & 0.00 & -0.14 & 1.08 & 0.11 & 0.03 & 0.35 & 0.11 & -0.07 & 0.45 & -0.02 & 31.76 \\
\hline$t$-stat & 0.04 & $-2.75^{*}$ & $19.64 *$ & $2.69 *$ & 0.67 & $8.67 *$ & $2.96^{*}$ & -1.23 & $6.42 *$ & -0.40 & \\
\hline Singapore & -0.00 & 0.01 & 0.92 & 0.12 & 0.07 & 0.41 & 0.10 & 0.01 & 0.28 & 0.06 & 20.89 \\
\hline$t$-stat & -0.65 & 0.21 & $12.15^{*}$ & 1.88 & 1.33 & $5.39 *$ & $2.35 \dagger$ & 0.10 & $2.98^{*}$ & 0.83 & \\
\hline Spain & 0.00 & 0.09 & 0.87 & -0.09 & 0.10 & 0.38 & -0.04 & -0.00 & 0.33 & -0.06 & 17.81 \\
\hline$t$-stat & 0.22 & 1.85 & $14.99 *$ & -1.65 & $3.05 *$ & $9.81 *$ & -1.22 & -0.07 & $5.24 *$ & -1.02 & \\
\hline Swiss H. & 0.00 & 0.03 & 0.70 & 0.01 & 0.12 & 0.27 & 0.04 & -0.08 & 0.30 & 0.01 & 20.36 \\
\hline$t$-stat & 1.45 & 0.81 & $15.80 *$ & 0.13 & $3.42 *$ & $4.84 *$ & 0.87 & -1.66 & $4.37 *$ & 0.14 & \\
\hline \multicolumn{12}{|c|}{ Panel B. Emerging Markets } \\
\hline Argentina & -0.00 & 0.17 & 1.07 & -0.05 & 0.08 & 0.58 & 0.09 & -0.02 & 0.26 & -0.06 & 44.43 \\
\hline$t$-stat & -0.70 & $2.57 \dagger$ & $15.59 *$ & -0.80 & $2.80 *$ & $17.72 *$ & $2.38 \dagger$ & 0.30 & $2.75^{*}$ & -0.65 & \\
\hline Brazil & 0.00 & 0.01 & 1.18 & -0.01 & -0.02 & 0.52 & 0.04 & -0.04 & 0.46 & -0.08 & 41.90 \\
\hline$t$-stat & $2.41 \dagger$ & 0.06 & $16.73^{*}$ & -0.22 & -0.71 & $12.85^{*}$ & 1.15 & -0.55 & $5.81 *$ & -1.23 & \\
\hline Brazilian E. & 0.00 & -0.14 & 1.61 & -0.03 & -0.10 & 0.74 & 0.02 & -0.05 & 0.21 & 0.07 & 53.07 \\
\hline$t$-stat & $2.72 *$ & $-1.96 \dagger$ & $21.31^{*}$ & -0.43 & $-2.66^{*}$ & $19.12 *$ & 0.66 & -0.54 & $2.18 \dagger$ & 0.81 & \\
\hline Chile & 0.00 & 0.03 & 0.58 & -0.02 & 0.18 & 0.64 & 0.13 & 0.02 & 0.33 & -0.05 & 32.79 \\
\hline$t$-stat & $2.15 \dagger$ & 0.52 & $11.84 *$ & -0.47 & $4.34 *$ & $14.01 *$ & $2.80 *$ & 0.43 & $5.10^{*}$ & -0.88 & \\
\hline China & -0.00 & -0.13 & 1.17 & -0.05 & 0.08 & 0.35 & 0.06 & 0.01 & 0.32 & -0.10 & 31.50 \\
\hline$t$-stat & -1.00 & $-1.98 \dagger$ & $8.14 *$ & -0.41 & $2.02 \dagger$ & $14.52 *$ & 1.93 & 0.08 & $2.03 \dagger$ & -1.00 & \\
\hline F. Philippine & -0.00 & -0.12 & 0.90 & 0.11 & 0.04 & 0.46 & 0.26 & -0.19 & 0.24 & 0.03 & 24.89 \\
\hline$t$-stat & -0.67 & -1.39 & $10.03^{*}$ & 1.59 & 0.82 & $8.76^{*}$ & $5.07 *$ & -1.73 & $2.23 \dagger$ & 0.37 & \\
\hline G. China & -0.00 & -0.27 & 1.48 & -0.05 & 0.06 & 0.43 & 0.10 & -0.10 & 0.23 & 0.02 & 37.68 \\
\hline$t$-stat & -0.62 & $-3.15^{*}$ & $11.38^{*}$ & -0.44 & 1.47 & $14.65^{*}$ & $3.39 *$ & -0.87 & 1.59 & 0.19 & \\
\hline India G. & -0.00 & -0.09 & 0.84 & 0.00 & 0.01 & 0.69 & 0.06 & -0.03 & -0.07 & -0.19 & 39.46 \\
\hline$t$-stat & -0.54 & -1.44 & $10.90 *$ & 0.07 & 0.67 & $22.40 *$ & 1.90 & -0.32 & -0.96 & $-2.22 \dagger$ & \\
\hline Indonesia & -0.00 & -0.06 & 0.75 & 0.36 & 0.02 & 0.46 & 0.13 & 0.04 & 0.44 & -0.17 & 15.87 \\
\hline$t$-stat & -1.39 & -0.53 & $6.74 *$ & $3.44 *$ & 0.36 & $7.87 *$ & $2.80 *$ & 0.33 & $3.47 *$ & -1.35 & \\
\hline J.F. China & -0.00 & -0.29 & 1.38 & -0.01 & 0.02 & 0.38 & 0.08 & -0.25 & 0.29 & 0.00 & 33.76 \\
\hline$t$-stat & -1.16 & $-2.83 *$ & $10.77 *$ & -0.12 & 0.70 & $13.56^{*}$ & $2.42 \dagger$ & -1.74 & $2.15 \dagger$ & 0.02 & \\
\hline Korea & -0.00 & -0.33 & 1.20 & 0.07 & 0.00 & 0.58 & 0.16 & -0.23 & 0.41 & -0.11 & 34.49 \\
\hline$t$-stat & -0.24 & $-4.76^{*}$ & $14.26^{*}$ & 0.95 & 0.05 & $22.60 *$ & $5.49 *$ & $-2.52 \dagger$ & $5.53^{*}$ & -1.47 & \\
\hline Korean I. & -0.00 & -0.32 & 1.27 & -0.18 & -0.01 & 0.64 & 0.10 & -0.14 & 0.26 & -0.14 & 38.03 \\
\hline$t$-stat & -0.62 & $-2.72 *$ & $10.29 *$ & -1.75 & -0.41 & $17.27 *$ & $3.09 *$ & -0.96 & $1.96 \dagger$ & -1.22 & \\
\hline Malaysia & -0.00 & 0.05 & 1.19 & -0.01 & 0.06 & 0.41 & 0.12 & -0.12 & 0.41 & 0.08 & 21.23 \\
\hline$t$-stat & -0.61 & 0.68 & $12.20 *$ & -0.07 & 1.33 & $5.46^{*}$ & $2.42 \dagger$ & -1.36 & $4.00 *$ & 0.96 & \\
\hline
\end{tabular}


Table II: continued

\begin{tabular}{|c|c|c|c|c|c|c|c|c|c|c|c|}
\hline Mexico E\&I & 0.00 & 0.02 & 1.20 & -0.00 & 0.13 & 0.78 & -0.02 & -0.11 & 0.17 & -0.08 & 42.68 \\
\hline$t$-stat & 0.80 & 0.36 & $16.37 *$ & -0.07 & $3.83 *$ & $20.92 *$ & -0.61 & -1.47 & 1.75 & -1.02 & \\
\hline Mexico & 0.00 & -0.05 & 1.30 & 0.08 & 0.04 & 0.92 & 0.04 & -0.13 & 0.47 & -0.11 & 51.53 \\
\hline$t$-stat & 1.64 & -1.18 & $24.09 *$ & 1.76 & 1.50 & $27.66^{*}$ & 1.44 & $-2.24 \dagger$ & $7.08 *$ & -1.85 & \\
\hline ROC Taiwan & -0.00 & -0.21 & 0.97 & 0.08 & -0.01 & 0.63 & 0.08 & -0.11 & 0.38 & -0.08 & 26.92 \\
\hline$t$-stat & -0.26 & $-2.70 *$ & $11.06 *$ & 1.22 & -0.44 & $20.48 *$ & $2.15 \dagger$ & -1.24 & $4.61 *$ & -0.99 & \\
\hline Taiwan & 0.00 & -0.07 & 0.93 & 0.07 & -0.00 & 0.45 & 0.08 & 0.04 & 0.25 & -0.04 & 24.89 \\
\hline$t$-stat & 0.07 & -1.14 & $12.71 *$ & 1.06 & -0.07 & $16.49 *$ & $2.78 *$ & 0.56 & $3.47 *$ & -0.45 & \\
\hline Thai C. & -0.00 & 0.01 & 0.93 & 0.07 & 0.06 & 0.47 & 0.13 & -0.16 & 0.36 & -0.07 & 22.85 \\
\hline$t$-stat & -1.21 & 0.05 & $7.47 *$ & 0.61 & 1.57 & $11.46^{*}$ & $4.44^{*}$ & -1.33 & $2.35 \dagger$ & -0.56 & \\
\hline Thai & -0.00 & -0.04 & 0.97 & 0.09 & 0.08 & 0.39 & 0.15 & -0.12 & 0.31 & 0.09 & 23.98 \\
\hline$t$-stat & -1.10 & -0.42 & $9.84 *$ & 1.22 & $2.78 *$ & $13.04 *$ & $4.59 *$ & -1.15 & $3.26^{*}$ & 1.07 & \\
\hline Turkish I. & 0.00 & 0.05 & 0.93 & -0.00 & 0.09 & 0.43 & 0.03 & 0.11 & 0.27 & -0.15 & 26.56 \\
\hline$t$-stat & 0.56 & 0.42 & $9.01 *$ & -0.04 & $4.19 *$ & $16.30^{*}$ & 1.39 & 1.09 & $2.24 \dagger$ & -1.43 & \\
\hline
\end{tabular}

*Significant at the $1 \%$ level

$\dagger$ Significant at the 5\% level

Table III: Weekly Regressions

This table reports regression results based on the following specification:

$$
R_{t}^{\text {Fund }}=a^{\text {Fund }}+\sum_{-1}^{+1} \beta_{i} R_{w, t+i}+\sum_{-1}^{+1} \gamma_{i} V_{j, t+i}+\sum_{-1}^{+1} \phi_{i} V_{U . S ., t+i}+\varepsilon_{t}
$$

where $R_{t}^{\text {Fund }}$ is the weekly return on the country fund invested in country $j, R_{w}$ is the weekly return on the world market, $V_{j}$ is the weekly orthogonal local return, and $V_{U . S}$ is the weekly orthogonal U.S. return. Newey-West (1987) adjusted $t$-statistics are reported in the second row for each country fund.

\begin{tabular}{|c|c|c|c|c|c|c|c|c|c|c|c|}
\hline & \multirow[t]{2}{*}{$a^{\text {Fund }}$} & \multicolumn{3}{|c|}{$\beta$} & \multicolumn{3}{|c|}{$\gamma$} & \multicolumn{3}{|c|}{$\phi$} & \multirow{2}{*}{$\begin{array}{c}R^{2} \\
(\%)\end{array}$} \\
\hline & & $t-1$ & $t$ & $t+1$ & $t-1$ & $t$ & $t+1$ & $t-1$ & $t$ & $t+1$ & \\
\hline \multicolumn{12}{|c|}{ Panel A. Developed Markets } \\
\hline Austria & -0.00 & 0.22 & 0.94 & -0.08 & -0.00 & 0.40 & 0.11 & -0.27 & -0.03 & 0.22 & 25.22 \\
\hline$t$-stat & -0.27 & $2.10 \dagger$ & $10.02 *$ & -0.87 & -0.01 & $5.44 *$ & 1.49 & -1.45 & -0.14 & 1.46 & \\
\hline Australia & 0.00 & -0.02 & 0.76 & -0.16 & 0.20 & 0.55 & 0.01 & -0.09 & 0.15 & 0.14 & 31.02 \\
\hline$t$-stat & 0.75 & -0.40 & $10.01 *$ & $-2.21 \dagger$ & $2.86^{*}$ & $7.78 *$ & 0.24 & -0.89 & 1.21 & 1.15 & \\
\hline France G. & 0.00 & 0.04 & 1.19 & 0.05 & 0.14 & 0.92 & 0.05 & -0.24 & 0.28 & -0.05 & 57.21 \\
\hline$t$-stat & 0.70 & 0.76 & $16.81^{*}$ & 0.95 & $2.54 \dagger$ & $15.26^{*}$ & 0.86 & $-2.26 \dagger$ & $2.21 \dagger$ & -0.33 & \\
\hline Germany & 0.00 & 0.00 & 1.18 & 0.00 & 0.18 & 0.71 & 0.03 & -0.27 & 0.47 & -0.20 & 34.57 \\
\hline$t$-stat & 0.79 & 0.04 & $12.97 *$ & 0.01 & 1.76 & $5.93 *$ & 0.31 & -1.77 & $3.01 *$ & -1.25 & \\
\hline Italy & 0.00 & 0.20 & 0.92 & 0.06 & 0.18 & 0.53 & 0.08 & -0.09 & 0.14 & 0.01 & 29.46 \\
\hline$t$-stat & 0.71 & $2.69 *$ & $9.60 *$ & 0.72 & $3.02 *$ & $7.39 *$ & 1.51 & -0.71 & 0.99 & 0.06 & \\
\hline Japan E. & -0.00 & -0.07 & 1.14 & -0.16 & 0.00 & 0.69 & 0.15 & 0.12 & 0.68 & 0.63 & 31.46 \\
\hline$t$-stat & -1.62 & -0.60 & $9.68 *$ & -1.50 & 0.02 & $5.16^{*}$ & 1.26 & 0.46 & $2.15 \dagger$ & $2.30 \dagger$ & \\
\hline Japan OTC & -0.00 & -0.14 & 1.60 & 0.11 & -0.05 & 0.66 & 0.21 & -0.41 & 0.45 & 0.45 & 42.49 \\
\hline$t$-stat & -1.42 & -1.42 & $13.22 *$ & 1.07 & -0.49 & $5.16^{*}$ & 1.85 & -1.59 & 1.59 & 1.46 & \\
\hline N. Germany & -0.00 & 0.03 & 0.94 & 0.14 & 0.15 & 0.54 & 0.08 & -0.17 & 0.15 & 0.15 & 37.69 \\
\hline$t$-stat & -0.19 & 0.41 & $11.65^{*}$ & $2.31 \dagger$ & $2.28 \dagger$ & $8.33^{*}$ & 1.13 & -1.36 & 1.18 & 1.22 & \\
\hline Singapore & -0.00 & 0.15 & 1.01 & 0.00 & 0.06 & 0.41 & 0.18 & -0.33 & 0.21 & 0.01 & 28.89 \\
\hline$t$-stat & -1.18 & 1.50 & $6.55^{*}$ & 0.03 & 0.94 & $4.72 *$ & $3.14 *$ & $-2.22 \dagger$ & 0.93 & 0.05 & \\
\hline Spain & -0.00 & 0.11 & 1.01 & 0.12 & 0.14 & 0.51 & -0.02 & 0.04 & 0.19 & 0.02 & 36.01 \\
\hline$t$-stat & -0.32 & 1.37 & $12.55^{*}$ & 1.87 & $2.00 \dagger$ & $7.51 *$ & -0.32 & 0.32 & 1.42 & 0.16 & \\
\hline Swiss H. & 0.00 & 0.19 & 0.85 & -0.04 & 0.16 & 0.43 & 0.08 & -0.19 & 0.23 & 0.01 & 36.08 \\
\hline$t$-stat & 1.08 & $3.35 *$ & $15.21 *$ & -0.81 & $2.24 \dagger$ & $4.05^{*}$ & 1.30 & -1.93 & 1.93 & 0.16 & \\
\hline
\end{tabular}


Table III: continued

\begin{tabular}{|c|c|c|c|c|c|c|c|c|c|c|c|}
\hline \multirow{2}{*}{\multicolumn{12}{|c|}{ Panel B. Emerging Markets }} \\
\hline & & & & & & & & & & & \\
\hline Argentina & -0.00 & 0.09 & 1.26 & -0.15 & 0.05 & 0.80 & -0.04 & -0.10 & -0.06 & 0.20 & 70.20 \\
\hline$t$-stat & -0.73 & 1.11 & $17.23^{*}$ & $-2.26 \dagger$ & 1.02 & $15.69 *$ & -0.94 & -0.62 & -0.45 & 1.60 & \\
\hline Brazil & 0.00 & 0.17 & 1.23 & -0.01 & -0.06 & 0.48 & -0.07 & 0.13 & 0.39 & 0.10 & 51.85 \\
\hline$t$-stat & 1.66 & 1.74 & $11.79 *$ & -0.06 & $-2.11 \dagger$ & $14.93 *$ & $-2.42 \dagger$ & 0.73 & $2.12 \dagger$ & 0.62 & \\
\hline Brazilian E. & 0.01 & 0.17 & 1.75 & -0.19 & -0.05 & 0.68 & -0.01 & -0.15 & -0.04 & 0.05 & 66.82 \\
\hline$t$-stat & 1.62 & 1.74 & $14.92 *$ & $-2.03 \dagger$ & -1.02 & $9.61 *$ & -0.29 & -0.82 & -0.13 & 0.21 & \\
\hline Chile & 0.00 & 0.08 & 0.67 & -0.11 & 0.08 & 0.94 & -0.12 & -0.01 & 0.31 & 0.05 & 53.46 \\
\hline$t$-stat & $2.46 \dagger$ & 1.14 & $8.09 *$ & -1.33 & 1.49 & $16.19^{*}$ & $-2.43 \dagger$ & -0.09 & $2.42 \dagger$ & 0.38 & \\
\hline China & -0.00 & 0.12 & 1.29 & -0.05 & 0.15 & 0.44 & 0.04 & -0.32 & 0.36 & -0.12 & 50.98 \\
\hline$t$-stat & -1.25 & 0.87 & $10.10^{*}$ & -0.63 & $2.71 *$ & $8.85^{*}$ & 1.08 & -1.24 & 1.43 & -0.46 & \\
\hline F. Philippine & -0.00 & 0.11 & 1.00 & 0.02 & 0.05 & 0.76 & 0.09 & -0.10 & -0.01 & 0.04 & 49.33 \\
\hline$t$-stat & -1.01 & 0.69 & $8.07 *$ & 0.18 & 0.70 & $12.05^{*}$ & $2.06 \dagger$ & -0.76 & -0.07 & 0.26 & \\
\hline G. China & -0.00 & 0.08 & 1.45 & 0.04 & 0.09 & 0.56 & 0.05 & -0.27 & 0.24 & 0.07 & 58.80 \\
\hline$t$-stat & -1.06 & 0.53 & $10.43^{*}$ & 0.34 & 1.60 & $13.23^{*}$ & 1.26 & -1.14 & -0.93 & 0.30 & \\
\hline India $\mathrm{G}$. & -0.00 & -0.14 & 1.09 & -0.12 & -0.03 & 0.70 & 0.13 & -0.13 & -0.21 & 0.13 & 49.23 \\
\hline$t$-stat & -0.51 & -1.20 & $8.03 *$ & -1.07 & -0.55 & $11.66^{*}$ & $2.27 \dagger$ & -0.55 & -0.85 & 0.46 & \\
\hline Indonesia & -0.00 & 0.04 & 1.15 & -0.26 & 0.08 & 0.57 & -0.01 & 0.11 & 0.33 & -0.08 & 26.31 \\
\hline$t$-stat & -1.30 & 0.26 & $6.08 *$ & -1.63 & 0.91 & $7.94 *$ & -0.13 & 0.43 & 1.12 & -0.28 & \\
\hline J.F. China & -0.00 & 0.08 & 1.32 & 0.08 & 0.09 & 0.45 & 0.05 & -0.26 & 0.02 & -0.02 & 53.51 \\
\hline$t$-stat & -1.93 & 0.57 & $10.29 *$ & 0.94 & $2.05 \dagger$ & $11.22 *$ & 1.48 & -1.23 & 0.09 & -0.08 & \\
\hline Korea & -0.00 & -0.04 & 1.20 & -0.02 & -0.05 & 0.64 & 0.06 & -0.18 & -0.06 & 0.11 & 44.00 \\
\hline$t$-stat & -0.74 & -0.40 & $9.60 *$ & -0.19 & -1.00 & $14.55^{*}$ & 1.38 & -1.09 & -0.35 & 0.73 & \\
\hline Korean I. & -0.00 & -0.01 & 1.42 & -0.03 & 0.08 & 0.68 & -0.07 & -0.44 & -0.49 & 0.27 & 54.54 \\
\hline$t$-stat & -1.40 & -0.12 & $8.16^{*}$ & -0.26 & 1.50 & $11.03 *$ & -1.38 & $-2.01 \dagger$ & -1.86 & 1.43 & \\
\hline Malaysia & -0.00 & 0.01 & 1.23 & -0.09 & 0.02 & 0.62 & 0.17 & 0.06 & 0.28 & -0.08 & 34.92 \\
\hline$t$-stat & -0.53 & 0.09 & $10.05^{*}$ & -0.78 & 0.27 & $8.49^{*}$ & $2.63 *$ & 0.31 & 1.21 & -0.42 & \\
\hline Mexico E\&I & 0.00 & 0.05 & 1.25 & 0.09 & 0.11 & 0.86 & -0.06 & -0.15 & -0.18 & -0.05 & 58.88 \\
\hline$t$-stat & 0.62 & 0.46 & $10.26^{*}$ & 0.95 & $2.04 \dagger$ & $19.76^{*}$ & -1.42 & -1.02 & -0.92 & -0.38 & \\
\hline Mexico & 0.00 & -0.15 & 1.43 & 0.02 & -0.00 & 1.03 & 0.02 & -0.04 & 0.16 & -0.09 & 67.82 \\
\hline$t$-stat & $2.03 \dagger$ & -1.55 & $19.08 *$ & 0.36 & -0.05 & $22.49 *$ & 0.39 & -0.36 & 1.47 & -0.66 & \\
\hline ROC Taiwan & -0.00 & 0.08 & 0.93 & 0.01 & -0.08 & 0.74 & 0.10 & 0.05 & 0.18 & 0.26 & 42.32 \\
\hline$t$-stat & -0.59 & 0.75 & $8.24 *$ & 0.10 & -1.74 & $14.16^{*}$ & $2.06 \dagger$ & 0.31 & 1.09 & 1.69 & \\
\hline Taiwan & -0.00 & 0.04 & 1.04 & 0.12 & -0.02 & 0.54 & 0.05 & -0.10 & 0.35 & 0.03 & 38.25 \\
\hline$t$-stat & -0.10 & 0.37 & $10.42 *$ & 1.17 & -0.38 & $10.04 *$ & 1.17 & -0.65 & $2.07 \dagger$ & 0.19 & \\
\hline Thai C. & -0.00 & -0.03 & 1.43 & -0.05 & 0.02 & 0.68 & 0.03 & 0.02 & -0.10 & -0.46 & 55.34 \\
\hline$t$-stat & $-1.99 \dagger$ & -0.22 & $9.39 *$ & -0.29 & 0.47 & $14.78 *$ & 0.67 & 0.13 & -0.67 & $-2.06 \dagger$ & \\
\hline Thai & -0.00 & -0.02 & 1.22 & 0.28 & -0.06 & 0.61 & 0.05 & -0.43 & 0.28 & -0.26 & 41.79 \\
\hline$t$-stat & -1.68 & -0.15 & $7.67 *$ & 1.86 & -1.28 & $11.31^{*}$ & 0.83 & $-1.96 \dagger$ & 1.53 & -1.33 & \\
\hline Turkish I. & 0.00 & 0.06 & 1.20 & -0.26 & 0.08 & 0.49 & 0.06 & 0.01 & 0.05 & 0.43 & 49.02 \\
\hline$t$-stat & 0.55 & 0.56 & $9.61 *$ & $-2.15 \dagger$ & $3.38^{*}$ & $10.99 *$ & 1.87 & 0.05 & 0.25 & $2.08 \dagger$ & \\
\hline
\end{tabular}

*Significant at the $1 \%$ level

$\uparrow$ Significant at the 5\% level 
Table IV: Monthly Regressions

This table reports regression results based on the following specification:

$$
R_{t}^{\text {Fund }}=a^{\text {Fund }}+\sum_{-1}^{+1} \beta_{i} R_{w, t+i}+\sum_{-1}^{+1} \gamma_{i} V_{j, t+i}+\sum_{-1}^{+1} \phi_{i} V_{U . S ., t+i}+\varepsilon_{t}
$$

where $R_{t}^{\text {Fund }}$ is the monthly return on the country fund invested in country $j, R_{w}$ is the monthly return on the world market, $V_{j}$ is the monthly orthogonal local return, and $V_{U . S}$ is the monthly orthogonal U.S. return. Newey-West (1987) adjusted $t$-statistics are reported in the second row for each country fund.

\begin{tabular}{|c|c|c|c|c|c|c|c|c|c|c|c|}
\hline \multirow{2}{*}{\multicolumn{2}{|c|}{$a^{\text {Fund }}$}} & \multicolumn{3}{|c|}{$\beta$} & \multicolumn{3}{|c|}{$\gamma$} & \multicolumn{3}{|c|}{$\phi$} & \multirow{2}{*}{$\begin{array}{l}R^{2} \\
(\%)\end{array}$} \\
\hline & & $t-1$ & $t$ & $t+1$ & $t-1$ & $t$ & $t+1$ & $t-1$ & $t$ & $t+1$ & \\
\hline \multicolumn{12}{|c|}{ Panel A. Developed Markets } \\
\hline Austria & -0.01 & 0.07 & 1.33 & 0.14 & 0.03 & 0.63 & -0.03 & -0.33 & -0.06 & 0.17 & 45.85 \\
\hline$t$-stat & -0.64 & 0.41 & $6.88 *$ & 0.80 & 0.23 & $3.63 *$ & -0.22 & -1.55 & -0.20 & 0.58 & \\
\hline Australia & -0.01 & 0.22 & 1.07 & -0.04 & 0.23 & 0.72 & -0.17 & 0.08 & 0.14 & -0.02 & 51.08 \\
\hline$t$-stat & -1.14 & 1.18 & $8.58 *$ & -0.41 & $3.07 *$ & $5.71 *$ & $-2.37 \dagger$ & 0.38 & 0.71 & -0.09 & \\
\hline France G. & -0.00 & -0.17 & 1.37 & 0.16 & 0.22 & 0.85 & 0.09 & 0.23 & -0.18 & 0.05 & 76.85 \\
\hline$t$-stat & -0.56 & $-2.19 \dagger$ & $13.80 *$ & $2.79 *$ & $2.89 *$ & $9.01 *$ & 1.25 & 1.28 & -1.13 & 0.31 & \\
\hline Germany & 0.00 & 0.02 & 1.20 & 0.06 & 0.12 & 0.86 & 0.19 & -0.04 & -0.07 & -0.10 & 50.04 \\
\hline$t$-stat & 0.07 & 0.18 & $11.49 *$ & 0.53 & 1.39 & $6.62 *$ & 1.03 & -0.15 & -0.22 & -0.37 & \\
\hline Italy & 0.00 & 0.18 & 1.34 & -0.07 & -0.04 & 0.78 & -0.11 & 0.21 & 0.13 & -0.28 & 53.06 \\
\hline$t$-stat & 0.07 & 1.86 & $10.26^{*}$ & -0.43 & -0.45 & $11.01 *$ & -1.29 & 0.96 & 0.48 & -1.23 & \\
\hline Japan E. & -0.01 & -0.35 & 1.52 & 0.44 & -0.05 & 0.64 & 0.08 & -0.13 & 0.31 & -0.96 & 51.86 \\
\hline$t$-stat & -1.55 & -1.36 & $6.28 *$ & $2.04 \dagger$ & -0.20 & $2.54 \dagger$ & 0.44 & -0.25 & 0.40 & $-2.04 \dagger$ & \\
\hline Japan OTC & -0.01 & -0.08 & 1.64 & 0.16 & -0.48 & 1.01 & 0.32 & -0.84 & 0.57 & 0.07 & 56.53 \\
\hline$t$-stat & -1.32 & -0.42 & $10.02 *$ & 1.04 & -1.64 & $4.38 *$ & 1.43 & -1.28 & 1.08 & 0.25 & \\
\hline N. Germany & -0.01 & -0.11 & 1.19 & 0.20 & 0.22 & 0.66 & 0.05 & 0.22 & -0.10 & 0.28 & 65.62 \\
\hline$t$-stat & -1.33 & -0.81 & $9.41 *$ & $2.05 \dagger$ & $2.53 \dagger$ & $7.21 *$ & 0.55 & 1.15 & -0.58 & 1.75 & \\
\hline Singapore & -0.01 & -0.25 & 1.39 & -0.11 & 0.14 & 0.68 & 0.11 & 0.40 & -0.13 & 0.30 & 50.13 \\
\hline$t$-stat & -0.99 & -1.03 & $7.08 *$ & -0.60 & 0.88 & $2.77 *$ & 0.60 & 1.10 & -0.31 & 0.86 & \\
\hline Spain & 0.00 & 0.15 & 1.45 & -0.06 & 0.09 & 0.71 & 0.16 & -0.01 & -0.38 & -0.02 & 38.64 \\
\hline$t$-stat & 0.02 & 0.81 & $7.27 *$ & -0.34 & 0.47 & $5.91 *$ & 1.51 & -0.02 & -0.94 & -0.08 & \\
\hline Swiss H. & -0.00 & -0.14 & 0.98 & 0.11 & 0.11 & 0.58 & 0.03 & -0.08 & 0.13 & -0.14 & 57.58 \\
\hline$t$-stat & -0.10 & -1.57 & $9.42 *$ & 1.42 & 1.25 & $7.77 *$ & 0.43 & -0.55 & 1.00 & -0.77 & \\
\hline \multicolumn{12}{|c|}{ Panel B. Emerging Markets } \\
\hline Argentina & -0.00 & -0.03 & 1.51 & -0.24 & 0.03 & 0.81 & 0.06 & -0.05 & 0.22 & 0.07 & 72.44 \\
\hline$t$-stat & -0.92 & -0.24 & $12.83 *$ & $-2.23 \dagger$ & 0.32 & $11.10^{*}$ & 0.62 & -0.23 & 0.95 & 0.32 & \\
\hline Brazil & 0.01 & 0.24 & 1.34 & -0.06 & 0.01 & 0.25 & -0.02 & 0.33 & 0.42 & -0.01 & 46.72 \\
\hline$t$-stat & 1.17 & 1.46 & $6.47 *$ & -0.35 & 0.21 & $5.34 *$ & -0.53 & 0.99 & 1.36 & -0.03 & \\
\hline Brazilian E. & -0.00 & -0.12 & 1.71 & 0.06 & -0.01 & 0.44 & -0.17 & 0.29 & 0.34 & 0.08 & 52.37 \\
\hline$t$-stat & -0.51 & -0.65 & $7.82 *$ & 0.32 & -0.15 & $4.02 *$ & -1.66 & 0.76 & 0.79 & 0.19 & \\
\hline Chile & 0.01 & 0.19 & 0.85 & -0.11 & -0.09 & 0.89 & 0.25 & 0.13 & 0.38 & -0.44 & 63.05 \\
\hline$t$-stat & 1.24 & 1.12 & $5.90 *$ & -0.56 & -1.62 & $6.98 *$ & 1.88 & 0.45 & 1.35 & -1.35 & \\
\hline China & -0.01 & -0.68 & 1.46 & 0.56 & 0.01 & 0.62 & 0.04 & 0.17 & -0.04 & -0.72 & 68.10 \\
\hline$t$-stat & -0.83 & $-4.02 *$ & $7.18 *$ & $2.95^{*}$ & 0.18 & $6.16^{*}$ & 0.60 & 0.38 & -0.08 & -1.39 & \\
\hline F. Philippine & -0.01 & -0.09 & 1.33 & 0.20 & -0.06 & 0.90 & 0.02 & 0.23 & -0.17 & -0.23 & 69.11 \\
\hline$t$-stat & -1.66 & -0.73 & $7.94 *$ & 1.74 & -0.93 & $11.20 *$ & 0.22 & 1.05 & -0.56 & -0.82 & \\
\hline G. China & -0.01 & -0.56 & 1.57 & 0.63 & -0.00 & 0.65 & 0.09 & 0.37 & 0.18 & -0.62 & 72.30 \\
\hline$t$-stat & -1.30 & $-2.51 \dagger$ & $8.24 *$ & $3.56^{*}$ & -0.04 & $8.04 *$ & 1.36 & 1.17 & 0.43 & -1.24 & \\
\hline India G. & -0.01 & -0.38 & 0.77 & 0.10 & 0.12 & 0.89 & 0.07 & 0.53 & 0.30 & -0.18 & 59.31 \\
\hline$t$-stat & -0.78 & $-2.64 *$ & $3.74 *$ & 0.74 & 1.39 & $10.40 *$ & 0.70 & 1.35 & 0.52 & -0.42 & \\
\hline Indonesia & -0.01 & -0.56 & 1.24 & 0.21 & 0.08 & 0.67 & 0.03 & 0.35 & -0.25 & -0.02 & 45.23 \\
\hline$t$-stat & -1.28 & -1.42 & $6.38 *$ & 0.84 & 0.70 & $5.49 *$ & 0.20 & 0.82 & -0.52 & -0.06 & \\
\hline J.F. China & -0.02 & -0.41 & 1.57 & 0.51 & -0.04 & 0.56 & 0.07 & -0.05 & 0.42 & -0.59 & 68.67 \\
\hline$t$-stat & $-2.35 \dagger$ & $-2.59 *$ & $7.50 *$ & $2.47 \dagger$ & -0.50 & $7.24 *$ & 1.12 & -0.13 & 1.03 & -1.33 & \\
\hline Korea & -0.01 & 0.06 & 1.54 & 0.02 & -0.09 & 0.83 & -0.01 & 0.14 & -0.04 & 0.45 & 64.96 \\
\hline$t$-stat & -1.02 & 0.23 & $7.98 *$ & 0.15 & -1.06 & $11.87 *$ & -0.07 & 0.62 & -0.12 & 1.41 & \\
\hline Korean I. & -0.01 & -0.45 & 1.68 & 0.06 & 0.04 & 0.83 & -0.04 & 0.71 & -0.03 & 0.33 & 68.89 \\
\hline$t$-stat & -1.42 & $-3.09 *$ & $6.79 *$ & 0.36 & 0.50 & $15.27 *$ & -0.52 & 1.36 & -0.08 & 0.74 & \\
\hline Malaysia & 0.00 & -0.01 & 1.40 & -0.24 & -0.12 & 0.74 & 0.34 & 0.22 & 0.05 & -0.16 & 45.47 \\
\hline$t$-stat & 0.14 & -0.06 & $8.50 *$ & -1.09 & -0.65 & $3.87 *$ & $2.87 *$ & 0.79 & 0.13 & -0.34 & \\
\hline
\end{tabular}


Table IV: continued

\begin{tabular}{|c|c|c|c|c|c|c|c|c|c|c|c|}
\hline Mexico E\&I & 0.01 & -0.28 & 1.33 & -0.01 & 0.20 & 0.97 & -0.04 & -0.04 & -0.44 & 0.04 & 68.20 \\
\hline$t$-stat & 1.29 & -1.44 & $6.69 *$ & -0.05 & $2.28 \dagger$ & $13.09 *$ & -0.66 & -0.12 & -1.39 & 0.15 & \\
\hline Mexico & 0.01 & 0.14 & 1.40 & -0.20 & 0.15 & 0.97 & 0.05 & -0.32 & -0.03 & -0.44 & 67.27 \\
\hline$t$-stat & $2.04 \dagger$ & 1.03 & $10.29 *$ & -1.47 & 1.74 & $14.84 *$ & 0.70 & -1.49 & -0.12 & $-2.12 \dagger$ & \\
\hline ROC Taiwan & -0.00 & -0.05 & 1.07 & -0.03 & -0.04 & 0.64 & 0.04 & -0.09 & 0.43 & 0.18 & 59.36 \\
\hline$t$-stat & -0.72 & -0.27 & $6.38 *$ & -0.25 & -0.67 & $7.87 *$ & 0.62 & -0.30 & $1.99 \dagger$ & 0.61 & \\
\hline Taiwan & 0.00 & -0.36 & 1.39 & 0.09 & -0.07 & 0.57 & 0.02 & -0.42 & 0.29 & -0.10 & 42.48 \\
\hline$t$-stat & 0.71 & -1.69 & $5.54 *$ & 0.57 & -0.82 & $5.37 *$ & 0.27 & -1.19 & 0.89 & -0.25 & \\
\hline Thai C. & -0.02 & -0.04 & 1.95 & 0.43 & 0.05 & 0.80 & 0.07 & 0.13 & 0.03 & 0.07 & 64.26 \\
\hline$t$-stat & $-2.51 *$ & -0.12 & $7.72 *$ & 1.41 & 0.47 & $18.92 *$ & 0.97 & 0.29 & 0.08 & 0.15 & \\
\hline Thai & -0.01 & 0.21 & 1.67 & 0.35 & 0.12 & 0.76 & 0.03 & 0.16 & -0.43 & -0.30 & 55.26 \\
\hline$t$-stat & -1.58 & 1.05 & $10.69 *$ & 1.21 & 1.36 & $13.20 *$ & 0.73 & 0.42 & -1.03 & -0.77 & \\
\hline Turkish I. & 0.01 & -0.12 & 1.25 & -0.10 & 0.05 & 0.59 & 0.05 & 0.14 & 0.13 & -0.42 & 67.99 \\
\hline$t$-stat & 0.62 & -0.67 & $5.02 *$ & -0.42 & 1.11 & $8.35 *$ & 1.17 & 0.39 & 0.36 & -1.02 & \\
\hline
\end{tabular}

*Significant at the $1 \%$ level

$\dagger$ Significant at the 5\% level

Table V: Daily Regressions with the Use of NYSE Smallest Decile Returns

This table reports regression results based on the following specification:

$$
R_{t}^{\text {Fund }}=a^{\text {Fund }}+\sum_{-1}^{+1} \beta_{i} R_{w, t+i}+\sum_{-1}^{+1} \gamma_{i} V_{j, t+i}+\sum_{-1}^{+1} \phi_{i} V_{\text {Small }, t+i}+\varepsilon_{t}
$$

where $R_{t}^{F u n d}$ is the daily return on the country fund invested in country $j, R_{w}$ is the daily return on the world market, $V_{j}$ is the daily orthogonal local return, and $V_{\text {Small }}$ is the daily orthogonal NYSE smallest decile return. Newey-West (1987) adjusted $t$-statistics are reported in the second row for each country fund.

\begin{tabular}{|c|c|c|c|c|c|c|c|c|c|c|c|}
\hline \multirow{2}{*}{\multicolumn{2}{|c|}{$a^{\text {Fund }}$}} & \multicolumn{3}{|c|}{$\beta$} & \multicolumn{3}{|c|}{$\gamma$} & \multicolumn{3}{|c|}{$\phi$} & \multirow{2}{*}{$\begin{array}{c}R^{2} \\
(\%)\end{array}$} \\
\hline & & $t-1$ & $t$ & $t+1$ & $t-1$ & $t$ & $t+1$ & $t-1$ & $t$ & $t+1$ & \\
\hline \multicolumn{12}{|c|}{ Panel A. Developed Markets } \\
\hline Austria & -0.00 & 0.03 & 0.81 & 0.03 & 0.10 & 0.24 & 0.09 & 0.02 & 0.46 & -0.12 & 14.35 \\
\hline$t$-stat & -0.00 & 0.58 & $12.15^{*}$ & 0.54 & $2.36 \dagger$ & $5.28 *$ & $2.29 \dagger$ & 0.26 & $5.27 *$ & -1.69 & \\
\hline Australia & 0.00 & -0.05 & 0.68 & 0.07 & 0.10 & 0.35 & 0.05 & -0.11 & 0.55 & -0.07 & 17.36 \\
\hline$t$-stat & 0.49 & -1.19 & $10.69 *$ & 1.33 & $3.26 *$ & $10.47 *$ & 1.58 & -1.42 & $6.71 *$ & -1.04 & \\
\hline France G. & 0.00 & -0.04 & 1.13 & 0.05 & 0.17 & 0.63 & 0.06 & -0.18 & 0.72 & -0.11 & 38.03 \\
\hline$t$-stat & 1.04 & -0.92 & $21.91 *$ & 1.35 & $5.21 *$ & $17.46^{*}$ & 1.72 & $-2.60 *$ & $9.88^{*}$ & -1.62 & \\
\hline Germany & 0.00 & 0.00 & 0.95 & 0.01 & 0.16 & 0.33 & 0.17 & -0.28 & 0.66 & -0.01 & 17.91 \\
\hline$t$-stat & 0.99 & 0.06 & $14.16^{*}$ & 0.18 & $3.45^{*}$ & $5.11 *$ & $2.78 *$ & $-2.69 *$ & $6.92 *$ & -0.09 & \\
\hline Italy & 0.00 & 0.05 & 0.76 & 0.03 & 0.09 & 0.35 & -0.00 & 0.05 & 0.41 & -0.17 & 17.16 \\
\hline$t$-stat & 1.14 & 1.05 & $11.86^{*}$ & 0.56 & $2.86^{*}$ & $11.97 *$ & -0.13 & 0.74 & $5.37 *$ & $-2.38 \dagger$ & \\
\hline Japan E. & -0.00 & -0.27 & 1.44 & -0.04 & 0.01 & 0.54 & 0.11 & -0.37 & 0.65 & 0.07 & 28.70 \\
\hline$t$-stat & -1.24 & $-3.45 *$ & $13.26^{*}$ & -0.42 & 0.09 & $9.33 *$ & 1.73 & $-2.57 \dagger$ & $4.25^{*}$ & 0.53 & \\
\hline Japan OTC & -0.00 & -0.31 & 1.66 & 0.11 & -0.06 & 0.65 & 0.12 & -0.36 & 0.93 & 0.03 & 27.00 \\
\hline$t$-stat & -0.94 & $-4.54 *$ & $18.79 *$ & 1.42 & -1.02 & $8.44 *$ & 1.93 & $-2.87 *$ & $6.18^{*}$ & 0.22 & \\
\hline N. Germany & 0.00 & -0.15 & 1.09 & 0.10 & 0.02 & 0.36 & 0.09 & -0.13 & 0.63 & -0.07 & 32.85 \\
\hline$t$-stat & 0.09 & $-3.06 *$ & $20.71 *$ & $2.46 \dagger$ & 0.67 & $9.29 *$ & $2.52 \dagger$ & -1.93 & $8.18^{*}$ & -1.23 & \\
\hline Singapore & -0.00 & 0.01 & 0.92 & 0.11 & 0.07 & 0.42 & 0.10 & -0.03 & 0.43 & 0.05 & 21.33 \\
\hline$t$-stat & -0.62 & 0.22 & $12.28^{*}$ & 1.75 & 1.27 & $5.50 *$ & $2.17 \dagger$ & -0.35 & $4.10^{*}$ & 0.57 & \\
\hline Spain & 0.00 & 0.08 & 0.87 & -0.10 & 0.10 & 0.37 & -0.05 & -0.05 & 0.45 & -0.07 & 18.23 \\
\hline$t$-stat & 0.24 & 1.76 & $15.22 *$ & -1.86 & $3.05 *$ & $3.05 *$ & -1.29 & -0.70 & $6.06^{*}$ & -1.08 & \\
\hline Swiss H. & 0.00 & 0.03 & 0.69 & -0.01 & 0.12 & 0.27 & 0.03 & -0.09 & 0.44 & 0.01 & 21.18 \\
\hline$t$-stat & 1.48 & 0.73 & $16.47 *$ & -0.19 & $3.67 *$ & $4.88 *$ & 0.74 & -1.64 & $5.70 *$ & 0.15 & \\
\hline
\end{tabular}


Table V: continued

\begin{tabular}{|c|c|c|c|c|c|c|c|c|c|c|c|}
\hline \multicolumn{12}{|c|}{ Panel B. Emerging Markets } \\
\hline Argentina & -0.00 & 0.17 & 1.08 & -0.06 & 0.08 & 0.57 & 0.08 & -0.11 & 0.41 & -0.02 & 44.79 \\
\hline$t$-stat & -0.69 & $2.68^{*}$ & $16.62 *$ & -1.15 & $3.00 *$ & $17.55^{*}$ & $2.37 \dagger$ & -1.34 & $3.80 *$ & -0.24 & \\
\hline Brazil & 0.00 & -0.01 & 1.20 & -0.03 & -0.02 & 0.52 & 0.04 & -0.11 & 0.60 & -0.09 & 42.21 \\
\hline$t$-stat & $2.44 \dagger$ & -0.07 & $17.27 *$ & -0.46 & -0.67 & $12.83 *$ & 1.15 & -1.19 & $6.51 *$ & -1.18 & \\
\hline Brazilian E. & 0.00 & -0.13 & 1.61 & -0.05 & -0.09 & 0.74 & 0.02 & -0.09 & 0.38 & 0.14 & 53.32 \\
\hline$t$-stat & $2.70 *$ & -1.88 & $21.42 *$ & -0.76 & $-2.59 *$ & $19.07 *$ & 0.65 & -0.85 & $3.44 *$ & 1.50 & \\
\hline Chile & 0.00 & 0.02 & 0.59 & -0.03 & 0.18 & 0.63 & 0.13 & -0.01 & 0.45 & -0.05 & 33.17 \\
\hline$t$-stat & $2.17 \dagger$ & 0.44 & $12.31 *$ & -0.75 & $4.39 *$ & $13.78 *$ & $2.79 *$ & -0.20 & $6.12 *$ & -0.75 & \\
\hline China & -0.00 & -0.13 & 1.17 & -0.06 & 0.08 & 0.35 & 0.06 & -0.00 & 0.51 & -0.13 & 32.07 \\
\hline$t$-stat & -1.01 & $-1.99 \dagger$ & $8.46^{*}$ & -0.57 & $2.04 \dagger$ & $14.89 *$ & 1.83 & -0.03 & $2.75^{*}$ & -1.31 & \\
\hline F. Philippine & -0.00 & -0.12 & 0.90 & 0.10 & 0.04 & 0.46 & 0.25 & -0.27 & 0.39 & 0.01 & 25.29 \\
\hline$t$-stat & -0.66 & -1.38 & $10.28^{*}$ & 1.43 & 0.82 & $8.89 *$ & $4.99 *$ & $-2.04 \dagger$ & $3.04 *$ & 0.06 & \\
\hline G. China & -0.00 & -0.26 & 1.48 & -0.06 & 0.05 & 0.44 & 0.10 & -0.19 & 0.42 & -0.00 & 38.17 \\
\hline$t$-stat & -0.62 & $-3.12 *$ & $11.88^{*}$ & -0.61 & 1.41 & $14.91 *$ & $3.24 *$ & -1.42 & $2.46 \dagger$ & -0.03 & \\
\hline India $\mathrm{G}$. & -0.00 & -0.07 & 0.85 & -0.01 & 0.02 & 0.69 & 0.06 & 0.00 & 0.03 & -0.21 & 39.46 \\
\hline$t$-stat & -0.60 & -1.21 & $10.95^{*}$ & -0.13 & 0.68 & $22.49 *$ & 1.86 & 0.03 & 0.32 & $-2.00 \dagger$ & \\
\hline Indonesia & -0.00 & -0.06 & 0.76 & 0.34 & 0.01 & 0.46 & 0.13 & -0.02 & 0.65 & -0.22 & 16.27 \\
\hline$t$-stat & -1.37 & -0.56 & $6.85^{*}$ & $3.22 *$ & 0.30 & $7.96^{*}$ & $2.72 *$ & -0.13 & $4.76^{*}$ & -1.61 & \\
\hline J.F. China & -0.00 & -0.28 & 1.39 & -0.03 & 0.02 & 0.39 & 0.08 & -0.37 & 0.52 & -0.01 & 34.62 \\
\hline$t$-stat & -1.18 & $-2.81 *$ & $11.17 *$ & -0.40 & 0.62 & $13.72 *$ & $2.36 \dagger$ & $-2.14 \dagger$ & $3.33 *$ & -0.05 & \\
\hline Korea & -0.00 & -0.34 & 1.21 & 0.06 & 0.00 & 0.58 & 0.16 & -0.30 & 0.48 & -0.14 & 34.53 \\
\hline$t$-stat & -0.23 & $-5.01 *$ & $14.50^{*}$ & 0.85 & 0.05 & $22.52 *$ & $5.57 *$ & $-2.79 *$ & $5.62 *$ & -1.68 & \\
\hline Korean I. & -0.00 & -0.31 & 1.27 & -0.20 & -0.02 & 0.64 & 0.10 & -0.23 & 0.43 & -0.22 & 38.45 \\
\hline$t$-stat & -0.61 & $-2.74 *$ & $10.50^{*}$ & -1.92 & -0.48 & $17.29 *$ & $3.11 *$ & -1.41 & $2.96^{*}$ & -1.75 & \\
\hline Malaysia & -0.00 & 0.04 & 1.20 & -0.02 & 0.06 & 0.42 & 0.11 & -0.18 & 0.55 & 0.12 & 21.61 \\
\hline$t$-stat & -0.59 & 0.56 & $12.43^{*}$ & -0.27 & 1.35 & $5.52 *$ & $2.32 \dagger$ & -1.83 & $4.71 *$ & 1.27 & \\
\hline Mexico E\&I & 0.00 & 0.04 & 1.20 & -0.02 & 0.13 & 0.77 & -0.01 & -0.20 & 0.33 & -0.14 & 43.11 \\
\hline$t$-stat & 0.80 & 0.56 & $17.31 *$ & -0.27 & $4.11 *$ & $20.94 *$ & -0.44 & $-2.37 \dagger$ & $2.91 *$ & -1.60 & \\
\hline Mexico & 0.00 & -0.06 & 1.32 & 0.07 & 0.05 & 0.92 & 0.04 & -0.22 & 0.62 & -0.10 & 51.95 \\
\hline$t$-stat & 1.65 & -1.42 & $24.97 *$ & 1.44 & 1.63 & $27.60 *$ & 1.44 & $-3.42 *$ & $8.02 *$ & -1.52 & \\
\hline ROC Taiwan & -0.00 & -0.22 & 0.98 & 0.08 & -0.02 & 0.64 & 0.07 & -0.17 & 0.45 & -0.12 & 26.96 \\
\hline$t$-stat & -0.25 & $-2.85^{*}$ & $11.18^{*}$ & 1.15 & -0.49 & $20.30 *$ & $2.11 \dagger$ & -1.60 & $4.86^{*}$ & -1.26 & \\
\hline Taiwan & 0.00 & -0.08 & 0.94 & 0.06 & -0.00 & 0.46 & 0.08 & 0.01 & 0.36 & -0.03 & 25.09 \\
\hline$t$-stat & 0.09 & -1.19 & $13.01 *$ & 0.90 & -0.11 & $16.54 *$ & $2.76^{*}$ & 0.09 & $4.41 *$ & -0.35 & \\
\hline Thai C. & -0.00 & -0.00 & 0.93 & 0.06 & 0.06 & 0.47 & 0.13 & -0.15 & 0.53 & -0.11 & 23.08 \\
\hline$t$-stat & -1.18 & -0.02 & $7.48^{*}$ & 0.49 & 1.66 & $11.55^{*}$ & $4.29 *$ & -1.11 & $3.00 *$ & -0.78 & \\
\hline Thai & -0.00 & -0.03 & 0.98 & 0.07 & 0.08 & 0.40 & 0.15 & -0.15 & 0.50 & 0.08 & 24.47 \\
\hline$t$-stat & -1.09 & -0.41 & $9.93^{*}$ & 0.97 & $2.74 *$ & $13.37 *$ & $4.46^{*}$ & -1.23 & $4.75^{*}$ & 0.88 & \\
\hline Turkish I. & 0.00 & 0.05 & 0.94 & -0.02 & 0.09 & 0.43 & 0.03 & 0.11 & 0.40 & -0.14 & 26.68 \\
\hline$t$-stat & 0.58 & 0.42 & $8.98^{*}$ & -0.24 & $4.14 *$ & $16.24 *$ & 1.38 & 0.80 & $2.81 *$ & -1.18 & \\
\hline
\end{tabular}

*Significant at the $1 \%$ level

$\uparrow$ Significant at the 5\% level 
Table VI: Weekly Regressions with the Use of NYSE Smallest Decile Returns

This table reports regression results based on the following specification:

$$
R_{t}^{\text {Fund }}=a^{\text {Fund }}+\sum_{-1}^{+1} \beta_{i} R_{w, t+i}+\sum_{-1}^{+1} \gamma_{i} V_{j, t+i}+\sum_{-1}^{+1} \phi_{i} V_{\text {Small }, t+i}+\varepsilon_{t}
$$

where $R_{t}^{\text {Fund }}$ is the weekly return on the country fund invested in country $j, R_{w}$ is the weekly return on the world market, $V_{j}$ is the weekly orthogonal local return, and $V_{\text {Small }}$ is the weekly orthogonal NYSE smallest decile return. Newey-West (1987) adjusted $t$ statistics are reported in the second row for each country fund.

\begin{tabular}{|c|c|c|c|c|c|c|c|c|c|c|c|}
\hline \multirow{2}{*}{\multicolumn{2}{|c|}{$a^{\text {Fund }}$}} & \multicolumn{3}{|c|}{$\beta$} & \multicolumn{3}{|c|}{$\gamma$} & \multicolumn{3}{|c|}{$\phi$} & \multirow{2}{*}{$\begin{array}{c}R^{2} \\
(\%) \\
\end{array}$} \\
\hline & & $t-1$ & $t$ & $t+1$ & $t-1$ & $t$ & $t+1$ & $t-1$ & $t$ & $t+1$ & \\
\hline \multicolumn{12}{|c|}{ Panel A. Developed Markets } \\
\hline Austria & -0.00 & 0.23 & 0.93 & -0.09 & -0.01 & 0.42 & 0.08 & -0.46 & 0.08 & -0.00 & 25.81 \\
\hline$t$-stat & -0.31 & $2.22 \dagger$ & $10.06^{*}$ & -0.97 & -0.06 & $6.15 *$ & 1.22 & $-1.97 \dagger$ & 0.34 & -0.00 & \\
\hline Australia & 0.00 & -0.02 & 0.76 & -0.16 & 0.20 & 0.55 & 0.01 & -0.09 & 0.21 & 0.13 & 31.13 \\
\hline$t$-stat & 0.74 & -0.46 & $10.02 *$ & $-2.19 \dagger$ & $2.87 *$ & $7.67 *$ & 0.17 & -0.92 & 1.52 & 0.99 & \\
\hline France G. & 0.00 & 0.05 & 1.18 & 0.05 & 0.14 & 0.92 & 0.05 & -0.31 & 0.38 & -0.10 & 57.82 \\
\hline$t$-stat & 0.70 & 0.83 & $17.21 *$ & 0.87 & $2.56+$ & $15.62 *$ & 0.86 & $-2.60 *$ & $3.03 *$ & -0.64 & \\
\hline Germany & 0.00 & 0.00 & 1.19 & -0.00 & 0.19 & 0.70 & 0.03 & -0.29 & 0.56 & -0.20 & 34.69 \\
\hline$t$-stat & 0.77 & 0.01 & $13.14 *$ & -0.03 & 1.88 & $5.91 *$ & 0.33 & -1.75 & $3.38 *$ & -1.19 & \\
\hline Italy & 0.00 & 0.20 & 0.92 & 0.06 & 0.18 & 0.53 & 0.08 & -0.11 & 0.24 & -0.02 & 29.70 \\
\hline$t$-stat & 0.70 & $2.69 *$ & $9.78 *$ & 0.68 & $3.06^{*}$ & $7.39 *$ & 1.51 & -0.77 & 1.59 & -0.11 & \\
\hline Japan E. & -0.00 & -0.09 & 1.13 & -0.14 & 0.00 & 0.71 & 0.12 & 0.10 & 0.76 & 0.49 & 31.44 \\
\hline$t$-stat & -1.45 & -0.78 & $10.10 *$ & -1.38 & 0.01 & $5.49 *$ & 1.34 & 0.45 & $2.74 *$ & $1.96 \dagger$ & \\
\hline Japan OTC & -0.00 & -0.15 & 1.59 & 0.11 & -0.06 & 0.65 & 0.18 & -0.54 & 0.50 & 0.33 & 42.56 \\
\hline$t$-stat & -1.43 & -1.53 & $13.00 *$ & 1.11 & -0.66 & $5.36^{*}$ & 1.78 & $-2.12 \dagger$ & 1.82 & 1.21 & \\
\hline N. Germany & -0.00 & 0.03 & 0.94 & 0.14 & 0.16 & 0.55 & 0.08 & -0.15 & 0.27 & 0.14 & 38.05 \\
\hline$t$-stat & -0.14 & 0.40 & $12.07 *$ & $2.26 \dagger$ & $2.43 \dagger$ & $8.48 *$ & 1.18 & -1.23 & $2.06 \dagger$ & 1.18 & \\
\hline Singapore & -0.00 & 0.14 & 1.01 & -0.01 & 0.06 & 0.41 & 0.18 & -0.29 & 0.36 & 0.04 & 29.07 \\
\hline$t$-stat & -1.12 & 1.42 & $6.67 *$ & -0.06 & 0.96 & $4.77 *$ & $3.19 *$ & -1.82 & 1.50 & 0.23 & \\
\hline Spain & -0.00 & 0.11 & 1.00 & 0.12 & 0.12 & 0.51 & -0.02 & -0.02 & 0.25 & -0.06 & 36.23 \\
\hline$t$-stat & -0.32 & 1.40 & $12.66^{*}$ & 1.89 & 1.90 & $7.56^{*}$ & -0.43 & -0.17 & 1.63 & -0.46 & \\
\hline Swiss H. & 0.00 & 0.19 & 0.85 & -0.04 & 0.16 & 0.42 & 0.07 & -0.20 & 0.36 & -0.01 & 36.90 \\
\hline$t$-stat & 1.07 & $3.38 *$ & $15.48 *$ & -0.82 & $2.34 \dagger$ & $4.01 *$ & 1.26 & $-2.04 \dagger$ & $2.99 *$ & -0.10 & \\
\hline \multicolumn{12}{|c|}{ Panel B. Emerging Markets } \\
\hline Argentina & -0.00 & 0.09 & 1.25 & -0.15 & 0.05 & 0.80 & -0.04 & -0.18 & 0.05 & 0.29 & 70.33 \\
\hline$t$-stat & -0.73 & 1.18 & $16.98 *$ & $-2.24 \dagger$ & 1.07 & $15.82 *$ & -0.97 & -0.99 & 0.36 & $2.26 \dagger$ & \\
\hline Brazil & 0.00 & 0.17 & 1.23 & -0.01 & -0.06 & 0.48 & -0.07 & 0.11 & 0.50 & 0.17 & 52.13 \\
\hline$t$-stat & 1.69 & 1.68 & $12.03 *$ & -0.07 & $-2.11 \dagger$ & $14.99 *$ & $-2.45 \dagger$ & 0.54 & $2.57 \dagger$ & 1.03 & \\
\hline Brazilian E. & 0.01 & 0.16 & 1.74 & -0.19 & -0.06 & 0.68 & -0.01 & 0.02 & 0.14 & 0.04 & 66.81 \\
\hline$t$-stat & 1.60 & 1.66 & $14.85^{*}$ & $-2.02 \dagger$ & -1.14 & $9.59 *$ & -0.17 & 0.08 & 0.58 & 0.15 & \\
\hline Chile & 0.00 & 0.08 & 0.67 & -0.11 & 0.08 & 0.93 & -0.13 & -0.03 & 0.42 & 0.11 & 53.81 \\
\hline$t$-stat & $2.46 \dagger$ & 1.08 & $8.31 *$ & -1.38 & 1.46 & $16.03 *$ & $-2.54 \dagger$ & -0.21 & $3.01 *$ & 0.71 & \\
\hline China & -0.00 & 0.11 & 1.29 & -0.06 & 0.14 & 0.44 & 0.03 & -0.34 & 0.51 & -0.13 & 51.45 \\
\hline$t$-stat & -1.29 & 0.78 & $10.00 *$ & -0.63 & $2.58 *$ & $8.62 *$ & 0.96 & -1.33 & $1.97 \dagger$ & -0.54 & \\
\hline F. Philippine & -0.00 & 0.11 & 0.99 & 0.02 & 0.05 & 0.76 & 0.09 & -0.14 & 0.08 & 0.03 & 49.39 \\
\hline$t$-stat & -1.02 & 0.71 & $8.15^{*}$ & 0.22 & 0.72 & $11.85^{*}$ & $1.98 \dagger$ & -0.92 & 0.40 & 0.15 & \\
\hline G. China & -0.00 & 0.11 & 1.45 & 0.04 & 0.09 & 0.56 & 0.04 & -0.31 & 0.29 & 0.01 & 58.90 \\
\hline$t$-stat & -1.06 & 0.48 & $10.40 *$ & 0.36 & 1.56 & $13.68^{*}$ & 1.17 & -1.34 & 1.03 & 0.04 & \\
\hline India G. & -0.00 & -0.14 & 1.08 & -0.13 & -0.04 & 0.70 & 0.13 & -0.21 & -0.25 & 0.11 & 49.31 \\
\hline$t$-stat & -0.49 & -1.17 & $8.07 *$ & -1.09 & -0.64 & $11.87^{*}$ & $2.27 \dagger$ & -0.86 & -1.12 & 0.38 & \\
\hline Indonesia & -0.00 & 0.05 & 1.14 & -0.25 & 0.07 & 0.57 & -0.01 & 0.15 & 0.57 & -0.09 & 26.72 \\
\hline$t$-stat & -1.28 & 0.33 & $6.16^{*}$ & -1.56 & 0.86 & $8.04 *$ & -0.14 & 0.58 & 1.86 & -0.32 & \\
\hline J.F. China & -0.00 & 0.09 & 1.31 & 0.08 & 0.09 & 0.45 & 0.05 & -0.41 & 0.02 & -0.09 & 53.91 \\
\hline$t$-stat & -1.91 & 0.58 & $10.30 *$ & 0.90 & $2.01 \dagger$ & $11.47^{*}$ & 1.47 & -2.01 & 0.06 & -0.41 & \\
\hline Korea & -0.00 & -0.03 & 1.20 & -0.02 & -0.04 & 0.64 & 0.06 & -0.22 & -0.11 & 0.09 & 44.05 \\
\hline$t$-stat & -0.75 & -0.37 & $9.62 *$ & -0.24 & -1.01 & $14.58 *$ & 1.35 & -1.25 & -0.60 & 0.59 & \\
\hline Korean I. & -0.00 & -0.04 & 1.38 & -0.05 & 0.09 & 0.69 & -0.06 & -0.24 & -0.10 & 0.35 & 53.75 \\
\hline$t$-stat & -1.41 & -0.33 & $7.61 *$ & -0.38 & 1.68 & $10.81 *$ & -1.27 & -1.08 & -0.39 & 1.65 & \\
\hline Malaysia & -0.00 & 0.01 & 1.23 & -0.09 & 0.02 & 0.62 & 0.16 & 0.08 & 0.39 & -0.07 & 35.14 \\
\hline \multirow[t]{2}{*}{$t$-stat } & -0.52 & 0.06 & $10.13 *$ & -0.77 & 0.24 & $8.51 *$ & $2.60 *$ & 0.40 & 1.59 & -0.39 & \\
\hline & & & & & 136 & & & & & & \\
\hline
\end{tabular}


Table VI: continued

\begin{tabular}{|c|c|c|c|c|c|c|c|c|c|c|c|}
\hline Mexico E\&I & 0.00 & 0.05 & 1.25 & 0.08 & 0.11 & 0.86 & -0.06 & -0.17 & -0.14 & -0.04 & 58.86 \\
\hline$t$-stat & 0.62 & 0.48 & $10.25 *$ & 0.85 & $2.04 \dagger$ & $19.55 *$ & -1.41 & -1.09 & -0.69 & -0.29 & \\
\hline Mexico & 0.00 & -0.15 & 1.43 & 0.02 & -0.00 & 1.02 & 0.02 & -0.05 & 0.27 & -0.07 & 67.97 \\
\hline$t$-stat & $2.04 \dagger$ & -1.57 & $19.08 *$ & 0.30 & -0.05 & $22.32 *$ & 0.39 & -0.40 & $2.47 \dagger$ & -0.51 & \\
\hline ROC Taiwan & -0.00 & 0.08 & 0.93 & 0.01 & -0.08 & 0.74 & 0.10 & 0.01 & 0.22 & 0.30 & 42.42 \\
\hline$t$-stat & -0.58 & 0.78 & $8.36 *$ & 0.12 & -1.75 & $14.25 *$ & $2.10 \dagger$ & 0.06 & 1.27 & 1.88 & \\
\hline Taiwan & -0.00 & 0.03 & 1.03 & 0.11 & -0.02 & 0.54 & 0.05 & -0.18 & 0.36 & 0.03 & 38.32 \\
\hline$t$-stat & -0.08 & 0.30 & $10.53 *$ & 1.11 & -0.40 & $10.03 *$ & 1.18 & -1.10 & $2.02+$ & 0.15 & \\
\hline Thai C. & -0.00 & -0.03 & 1.43 & -0.05 & 0.02 & 0.69 & 0.04 & -0.08 & -0.13 & -0.50 & 55.42 \\
\hline$t$-stat & $-2.03 \dagger$ & -0.18 & $9.42 *$ & -0.33 & 0.42 & $14.74 *$ & 0.73 & -0.43 & -0.74 & $-2.02 \dagger$ & \\
\hline Thai & -0.00 & -0.01 & 1.22 & 0.27 & -0.06 & 0.61 & 0.05 & -0.49 & 0.43 & -0.26 & 42.08 \\
\hline$t$-stat & -1.72 & -0.08 & $7.72 *$ & 1.85 & -1.26 & $11.26 *$ & 0.86 & $-2.10 \dagger$ & $2.13 \dagger$ & -1.23 & \\
\hline Turkish I. & 0.00 & 0.06 & 1.20 & -0.25 & 0.08 & 0.49 & 0.06 & 0.04 & 0.13 & 0.37 & 48.87 \\
\hline$t$-stat & 0.56 & 0.55 & $9.51 *$ & $-2.09 \dagger$ & $3.32 *$ & $10.94 *$ & 1.79 & 0.18 & 0.58 & 1.70 & \\
\hline
\end{tabular}

*Significant at the $1 \%$ level

$\dagger$ Significant at the 5\% level

Table VII: Monthly Regressions with the Use of NYSE Smallest Decile Returns

This table reports regression results based on the following specification:

$$
R_{t}^{\text {Fund }}=a^{\text {Fund }}+\sum_{-1}^{+1} \beta_{i} R_{w, t+i}+\sum_{-1}^{+1} \gamma_{i} V_{j, t+i}+\sum_{-1}^{+1} \phi_{i} V_{\text {Small }, t+i}+\varepsilon_{t}
$$

where $R_{t}^{\text {Fund }}$ is the monthly return on the country fund invested in country $j, R_{w}$ is the monthly return on the world market, $V_{j}$ is the monthly orthogonal local return, and $V_{\text {Small }}$ is the monthly orthogonal NYSE smallest decile return. Newey-West (1987) adjusted $t$-statistics are reported in the second row for each country fund.

\begin{tabular}{|c|c|c|c|c|c|c|c|c|c|c|c|}
\hline \multirow{2}{*}{\multicolumn{2}{|c|}{$a^{\text {Fund }}$}} & \multicolumn{3}{|c|}{$\beta$} & \multicolumn{3}{|c|}{$\gamma$} & \multicolumn{3}{|c|}{$\phi$} & \multirow{2}{*}{$\begin{array}{l}R^{2} \\
(\%)\end{array}$} \\
\hline & & $t-1$ & $t$ & $t+1$ & $t-1$ & $t$ & $t+1$ & $t-1$ & $t$ & $t+1$ & \\
\hline \multicolumn{12}{|c|}{ Panel A. Developed Markets } \\
\hline Austria & -0.00 & 0.07 & 1.32 & 0.14 & 0.07 & 0.65 & -0.01 & -0.41 & -0.40 & -0.12 & 46.81 \\
\hline$t$-stat & -0.49 & 0.39 & $7.26 *$ & 0.80 & 0.62 & $3.74 *$ & -0.05 & -1.55 & -1.09 & 0.38 & \\
\hline Australia & -0.01 & 0.22 & 1.07 & -0.04 & 0.23 & 0.72 & -0.18 & 0.09 & 0.14 & 0.08 & 51.13 \\
\hline$t$-stat & -1.16 & 1.16 & $8.34 *$ & -0.37 & $3.03 *$ & $5.47 *$ & $-2.37 \dagger$ & 0.41 & 0.67 & 0.32 & \\
\hline France G. & -0.00 & -0.16 & 1.36 & 0.18 & 0.20 & 0.85 & 0.10 & 0.18 & -0.18 & -0.02 & 76.61 \\
\hline$t$-stat & -0.53 & $-2.10 \dagger$ & $13.47 *$ & $2.90 *$ & $2.71 *$ & $8.87 *$ & 1.41 & 1.05 & -1.36 & -0.16 & \\
\hline Germany & 0.00 & 0.02 & 1.20 & 0.06 & 0.12 & 0.86 & 0.19 & -0.06 & -0.01 & -0.07 & 49.98 \\
\hline$t$-stat & 0.05 & 0.15 & $11.78^{*}$ & 0.52 & 1.38 & $6.75^{*}$ & 1.02 & -0.21 & -0.03 & -0.26 & \\
\hline Italy & 0.00 & 0.17 & 1.34 & -0.07 & -0.04 & 0.78 & -0.11 & 0.18 & 0.13 & -0.30 & 52.98 \\
\hline$t$-stat & 0.10 & 1.71 & $10.28 *$ & -0.44 & -0.45 & $10.75^{*}$ & -1.33 & 0.78 & 0.48 & -1.21 & \\
\hline Japan E. & -0.01 & -0.36 & 1.53 & 0.34 & -0.06 & 0.68 & 0.30 & 0.21 & 0.47 & -0.05 & 50.17 \\
\hline$t$-stat & -1.37 & -1.37 & $7.72 *$ & 1.56 & -0.23 & $3.35^{*}$ & 1.50 & 0.39 & 0.93 & -0.13 & \\
\hline Japan OTC & -0.01 & -0.11 & 1.69 & 0.13 & -0.42 & 0.89 & 0.42 & -0.58 & 0.20 & 0.37 & 55.28 \\
\hline$t$-stat & -1.37 & -0.52 & $9.65^{*}$ & 0.88 & -1.69 & $4.28 *$ & 1.71 & -1.02 & 0.55 & 1.10 & \\
\hline N. Germany & -0.01 & -0.07 & 1.19 & 0.22 & 0.22 & 0.68 & 0.04 & 0.24 & -0.03 & 0.25 & 65.38 \\
\hline$t$-stat & -1.44 & -0.54 & $9.37 *$ & $2.28 \dagger$ & $2.51 \dagger$ & $7.34 *$ & 0.42 & 1.05 & -0.17 & 1.45 & \\
\hline Singapore & -0.01 & -0.21 & 1.37 & -0.08 & 0.14 & 0.68 & 0.10 & 0.47 & -0.11 & 0.22 & 50.15 \\
\hline$t$-stat & -1.05 & -0.87 & $7.29 *$ & -0.44 & 0.85 & $2.78 *$ & 0.58 & 1.27 & -0.28 & 0.67 & \\
\hline Spain & 0.00 & 0.16 & 1.44 & -0.08 & 0.08 & 0.72 & 0.15 & 0.05 & -0.38 & -0.14 & 38.67 \\
\hline$t$-stat & 0.02 & 0.88 & $6.94 *$ & -0.40 & 0.46 & $5.78 *$ & 1.53 & 0.11 & -0.97 & -0.41 & \\
\hline Swiss H. & -0.00 & -0.16 & 1.00 & 0.10 & 0.12 & 0.58 & 0.04 & -0.14 & 0.23 & -0.16 & 58.28 \\
\hline$t$-stat & -0.13 & -1.77 & $9.58 *$ & 1.31 & 1.37 & $7.75^{*}$ & 0.54 & -1.01 & 1.93 & -0.82 & \\
\hline
\end{tabular}


Table VII: continued

\begin{tabular}{|c|c|c|c|c|c|c|c|c|c|c|c|}
\hline \multicolumn{12}{|c|}{ Panel B. Emerging Markets } \\
\hline Argentina & -0.00 & -0.03 & 1.51 & -0.24 & 0.03 & 0.80 & 0.06 & -0.09 & 0.33 & 0.15 & 72.77 \\
\hline$t$-stat & -0.92 & -0.21 & $13.62 *$ & $-2.09 \dagger$ & 0.37 & $11.17 *$ & 0.60 & -0.49 & 1.34 & 0.71 & \\
\hline Brazil & 0.01 & 0.23 & 1.34 & -0.06 & 0.01 & 0.25 & -0.02 & 0.27 & 0.41 & -0.03 & 46.64 \\
\hline$t$-stat & 1.25 & 1.42 & $6.49 *$ & -0.30 & 0.18 & $5.46 *$ & -0.57 & 0.83 & 1.16 & -0.12 & \\
\hline Brazilian E. & -0.00 & -0.12 & 1.70 & 0.06 & -0.01 & 0.44 & -0.17 & 0.24 & 0.46 & 0.14 & 52.66 \\
\hline$t$-stat & -0.49 & -0.70 & $7.77 *$ & 0.30 & -0.13 & $4.05 *$ & -1.67 & 0.62 & 0.97 & 0.30 & \\
\hline Chile & 0.01 & 0.16 & 0.85 & -0.12 & -0.08 & 0.88 & 0.25 & 0.04 & 0.52 & -0.43 & 63.34 \\
\hline$t$-stat & 1.30 & 0.95 & $5.98 *$ & -0.59 & -1.46 & $6.87 *$ & 1.84 & 0.14 & 1.74 & -1.19 & \\
\hline China & -0.01 & -0.72 & 1.45 & 0.54 & 0.03 & 0.62 & 0.05 & -0.08 & 0.28 & -0.79 & 68.37 \\
\hline$t$-stat & -0.77 & $-3.94 *$ & $7.19 *$ & $3.07 *$ & 0.35 & $5.91 *$ & 0.66 & -0.16 & 0.60 & -1.62 & \\
\hline F. Philippine & -0.01 & -0.09 & 1.33 & 0.20 & -0.07 & 0.91 & 0.02 & 0.26 & -0.26 & -0.21 & 69.24 \\
\hline$t$-stat & -1.65 & -0.70 & $8.05^{*}$ & 1.86 & -1.02 & $11.37 *$ & 0.25 & 1.19 & -0.93 & -0.72 & \\
\hline G. China & -0.01 & -0.60 & 1.56 & 0.61 & 0.01 & 0.64 & 0.10 & 0.02 & 0.51 & -0.69 & 72.53 \\
\hline$t$-stat & -1.15 & $-2.65 *$ & $8.35 *$ & $3.78 *$ & 0.12 & $8.08 *$ & 1.34 & 0.05 & 1.36 & -1.41 & \\
\hline India $\mathrm{G}$. & -0.00 & -0.39 & 0.80 & 0.12 & 0.12 & 0.86 & 0.05 & 0.20 & 0.02 & -0.20 & 58.47 \\
\hline$t$-stat & -0.67 & $-2.53 \dagger$ & $3.85 *$ & 0.97 & 1.32 & $10.53 *$ & 0.55 & 0.57 & 0.03 & -0.54 & \\
\hline Indonesia & -0.01 & -0.51 & 1.25 & 0.21 & 0.09 & 0.66 & 0.02 & 0.15 & 0.19 & 0.35 & 45.15 \\
\hline$t$-stat & -1.27 & -1.31 & $6.19 *$ & 0.86 & 0.80 & $5.48 *$ & 0.12 & 0.39 & 0.45 & 0.74 & \\
\hline J.F. China & -0.02 & -0.45 & 1.58 & 0.47 & -0.04 & 0.56 & 0.08 & -0.21 & 0.50 & -0.44 & 68.56 \\
\hline$t$-stat & $-2.33 \dagger$ & $-2.76^{*}$ & $7.66^{*}$ & $2.39 \dagger$ & -0.43 & $7.93 *$ & 1.11 & -0.64 & 1.23 & -0.97 & \\
\hline Korea & -0.01 & 0.08 & 1.54 & 0.05 & -0.08 & 0.83 & -0.00 & 0.16 & -0.04 & 0.43 & 64.85 \\
\hline$t$-stat & -1.06 & 0.33 & $7.73 *$ & 0.34 & -0.99 & $11.99 *$ & -0.03 & 0.64 & -0.13 & 1.38 & \\
\hline Korean I. & -0.01 & -0.44 & 1.66 & 0.08 & 0.06 & 0.83 & -0.04 & 0.62 & 0.07 & 0.21 & 68.47 \\
\hline$t$-stat & -1.43 & $-2.57 *$ & $6.83^{*}$ & 0.48 & 0.68 & $14.03 *$ & -0.49 & 1.35 & 0.21 & 0.48 & \\
\hline Malaysia & 0.00 & 0.04 & 1.39 & -0.19 & -0.13 & 0.74 & 0.34 & 0.32 & -0.02 & 0.05 & 45.54 \\
\hline$t$-stat & 0.06 & 0.18 & $9.18 *$ & -0.88 & -0.69 & $3.91 *$ & $2.78 *$ & 1.04 & -0.04 & 0.13 & \\
\hline Mexico E\&I & 0.01 & -0.26 & 1.32 & 0.00 & 0.22 & 0.97 & -0.04 & -0.09 & -0.40 & 0.01 & 68.07 \\
\hline$t$-stat & 1.23 & -1.33 & $6.39 *$ & 0.00 & $2.39 \dagger$ & $12.98^{*}$ & -0.65 & -0.28 & -1.24 & 0.03 & \\
\hline Mexico & 0.01 & 0.10 & 1.45 & -0.21 & 0.15 & 0.97 & 0.04 & -0.36 & 0.13 & -0.33 & 67.13 \\
\hline$t$-stat & $1.96 \dagger$ & 0.66 & $10.17 *$ & -1.45 & 1.67 & $14.55^{*}$ & 0.55 & -1.61 & 0.53 & -1.51 & \\
\hline ROC Taiwan & -0.00 & -0.05 & 1.07 & -0.03 & -0.04 & 0.63 & 0.05 & -0.14 & 0.47 & 0.27 & 59.70 \\
\hline$t$-stat & -0.64 & -0.30 & $6.44 *$ & -0.30 & -0.65 & $7.70 *$ & 0.69 & -0.46 & $2.06+$ & 0.94 & \\
\hline Taiwan & 0.00 & -0.44 & 1.44 & 0.07 & -0.07 & 0.57 & 0.02 & -0.59 & 0.37 & -0.13 & 43.24 \\
\hline$t$-stat & 0.79 & $-2.00 \dagger$ & $5.47 *$ & 0.42 & -0.80 & $5.39 *$ & 0.27 & -1.61 & 1.16 & -0.35 & \\
\hline Thai C. & -0.02 & -0.04 & 1.94 & 0.44 & 0.05 & 0.80 & 0.07 & 0.01 & 0.02 & -0.05 & 64.23 \\
\hline$t$-stat & $-2.51 *$ & -0.11 & $7.74 *$ & 1.45 & 0.52 & $17.38^{*}$ & 1.00 & 0.01 & 0.03 & -0.13 & \\
\hline Thai & -0.01 & 0.21 & 1.68 & 0.35 & 0.13 & 0.77 & 0.04 & 0.10 & -0.49 & -0.33 & 55.34 \\
\hline$t$-stat & -1.64 & 1.02 & $10.32 *$ & 1.25 & 1.46 & $11.96^{*}$ & 0.76 & 0.31 & -1.04 & -0.89 & \\
\hline Turkish I. & 0.01 & -0.15 & 1.25 & -0.10 & 0.05 & 0.59 & 0.05 & 0.03 & 0.09 & -0.46 & 67.95 \\
\hline$t$-stat & 0.66 & -0.81 & $5.03 *$ & -0.41 & 1.07 & $8.37 *$ & 1.16 & 0.09 & 0.26 & -1.10 & \\
\hline
\end{tabular}

*Significant at the $1 \%$ level

$\dagger$ Significant at the 5\% level 
Table VIII: Time-Series Regressions with the Inclusion of Exchange Rate Risk-Developed Markets

This table reports regression results based on the following specification:

$$
R_{t}^{\text {Fund }}=a^{\text {Fund }}+\sum_{-1}^{+1} \beta_{i} R_{w, t+i}+\sum_{-1}^{+1} \gamma_{i} V_{j, t+i}+\sum_{-1}^{+1} \phi_{i} V_{\text {Small }, t+i}+\sum_{-1}^{+1} \psi_{i} E_{j, t+i}+\varepsilon_{t}
$$

where $R_{t}^{\text {Fund }}$ is the return on the country fund invested in country $j, R_{w}$ is the return on the world market, $V_{j}$ is the orthogonal local return, $V_{S m a l l}$ is the orthogonal NYSE smallest decile return, and $E_{j}$ is the percentage change in exchange rate $j$. Panels A and B report daily and monthly regression results, respectively. Newey-West (1987) adjusted $t$-statistics are reported in the second row for each country fund.

\begin{tabular}{|c|c|c|c|c|c|c|c|c|c|c|c|c|c|c|}
\hline & \multirow[t]{2}{*}{$a^{\text {Fund }}$} & \multicolumn{3}{|c|}{$\beta$} & \multicolumn{3}{|c|}{$\gamma$} & \multicolumn{3}{|c|}{$\phi$} & \multicolumn{3}{|c|}{$\psi$} & \multirow{2}{*}{$\begin{array}{c}R^{2} \\
(\%)\end{array}$} \\
\hline & & $t-1$ & $t$ & $t+1$ & $t-1$ & $t$ & $t+1$ & $t-1$ & $t$ & $t+1$ & $t-1$ & $t$ & $t+1$ & \\
\hline \multicolumn{15}{|c|}{ Panel A: Daily Regression } \\
\hline \multirow{2}{*}{ France G. ${ }_{t \text {-stat }}$} & 0.00 & -0.08 & 1.18 & 0.04 & 0.17 & 0.68 & 0.07 & -0.25 & 0.59 & -0.06 & 0.03 & -0.41 & 0.08 & 40.06 \\
\hline & 0.91 & -1.65 & $23.80^{*}$ & 1.09 & $5.13 *$ & $18.90 *$ & $1.98 \dagger$ & $-3.54 *$ & $7.59 *$ & -0.90 & 0.52 & $-6.69 *$ & 1.48 & \\
\hline Germany & 0.00 & -0.06 & 1.04 & 0.04 & 0.16 & 0.43 & 0.20 & -0.37 & 0.50 & -0.02 & 0.10 & -0.50 & -0.08 & 19.60 \\
\hline$t$-stat & 0.95 & -0.87 & $15.25^{*}$ & 0.57 & $3.20 *$ & $5.49 *$ & $2.94 *$ & $-3.56^{*}$ & $5.03^{*}$ & -0.19 & 1.31 & $-5.23 *$ & -1.20 & \\
\hline Japan E. & -0.00 & -0.36 & 1.53 & 0.04 & -0.02 & 0.71 & 0.19 & -0.47 & 0.56 & 0.02 & 0.15 & -0.51 & -0.27 & 31.46 \\
\hline$t$-stat & -1.18 & $-4.43 *$ & $14.57^{*}$ & 0.45 & -0.40 & $10.36^{*}$ & $2.78 *$ & $-3.23 *$ & $3.78^{*}$ & 0.16 & 1.96 & $-5.54 *$ & $-3.28 *$ & \\
\hline N. Germany & -0.00 & -0.20 & 1.15 & 0.11 & 0.02 & 0.45 & 0.10 & -0.22 & 0.49 & -0.06 & 0.10 & -0.47 & -0.00 & 35.83 \\
\hline$t$-stat & -0.13 & $-4.19^{*}$ & $22.91^{*}$ & $2.49 \dagger$ & 0.54 & $11.30^{*}$ & $2.67 *$ & $-3.11 *$ & $6.28 *$ & -0.92 & $2.02 \dagger$ & $-7.66^{*}$ & -0.08 & \\
\hline Swiss H. & 0.00 & 0.01 & 0.73 & -0.00 & 0.12 & 0.34 & 0.06 & -0.14 & 0.35 & 0.01 & 0.03 & -0.26 & -0.03 & 22.41 \\
\hline$t$-stat & 1.50 & 0.14 & $17.76^{*}$ & -0.08 & $2.99 *$ & $4.78^{*}$ & 1.07 & $-2.48 \dagger$ & $4.45^{*}$ & 0.18 & 0.66 & $-4.95 *$ & -0.56 & \\
\hline \multicolumn{15}{|c|}{ Panel B: Monthly Regression } \\
\hline \multirow{2}{*}{ France G. } & -0.00 & -0.18 & 1.37 & 0.18 & 0.24 & 0.82 & 0.07 & 0.13 & -0.17 & -0.01 & 0.27 & -0.34 & -0.92 & 78.39 \\
\hline & -0.89 & $-2.26 \dagger$ & $14.82 *$ & $2.99 *$ & $3.14 *$ & $8.50 *$ & 1.09 & 0.84 & -1.44 & -0.09 & 0.94 & -0.88 & $-2.43 \dagger$ & \\
\hline Germany & 0.00 & 0.04 & 1.17 & 0.05 & 0.18 & 0.89 & 0.21 & -0.04 & -0.04 & -0.00 & -1.67 & -0.44 & -1.30 & 52.06 \\
\hline$t$-stat & 0.38 & 0.32 & $12.35^{*}$ & 0.48 & 1.93 & $6.65^{*}$ & 1.23 & -0.12 & -0.14 & -0.02 & -1.61 & -0.75 & $-2.08 \dagger$ & \\
\hline Japan E. & -0.01 & -0.36 & 1.53 & 0.33 & -0.07 & 0.72 & 0.25 & 0.16 & 0.63 & -0.07 & 0.75 & 0.10 & 0.86 & 50.81 \\
\hline$t$-stat & -1.55 & -1.37 & $7.79 *$ & 1.45 & -0.29 & $3.62 *$ & 1.29 & 0.32 & 1.23 & -0.21 & 0.71 & 0.07 & 0.75 & \\
\hline N. Germany & -0.01 & -0.07 & 1.18 & 0.22 & 0.23 & 0.69 & 0.04 & 0.23 & -0.05 & 0.24 & -0.07 & 0.42 & 0.45 & 65.84 \\
\hline$t$-stat & -1.53 & -0.53 & $9.62 *$ & $2.33 \dagger$ & $2.48 \dagger$ & $7.30 *$ & 0.40 & 1.02 & -0.27 & 1.43 & -0.14 & 0.80 & 1.05 & \\
\hline \multirow{2}{*}{ Swiss H. ${ }_{t \text {-stat }}$} & -0.00 & -0.16 & 1.01 & 0.10 & 0.12 & 0.59 & 0.04 & -0.14 & 0.21 & -0.13 & -1.20 & 0.29 & 0.62 & 59.97 \\
\hline & -0.17 & -1.81 & $9.90 *$ & 1.26 & 1.34 & $8.08 *$ & 0.47 & -1.03 & 1.74 & -0.75 & $-2.13 \dagger$ & 0.59 & 1.05 & \\
\hline
\end{tabular}

$*$ Significant at the $1 \%$ level; $\uparrow$ Significant at the $5 \%$ level 
Table IX: Time-Series Regressions with the Inclusion of Exchange Rate Risk-Emerging Markets

This table reports regression results based on the following specification:

$$
R_{t}^{\text {Fund }}=a^{\text {Fund }}+\sum_{-1}^{+1} \beta_{i} R_{w, t+i}+\sum_{-1}^{+1} \gamma_{i} V_{j, t+i}+\sum_{-1}^{+1} \phi_{i} V_{\text {Small }, t+i}+\sum_{-1}^{+1} \psi_{i} E_{j, t+i}+\varepsilon_{t}
$$

where $R_{t}^{\text {Fund }}$ is the return on the country fund invested in country $j, R_{w}$ is the return on the world market, $V_{j}$ is the orthogonal local return, $V_{S m a l l}$ is the orthogonal NYSE smallest decile return, and $E_{j}$ is the percentage change in exchange rate $j$. Panels A and B report daily and monthly regression results, respectively. Newey-West (1987) adjusted $t$-statistics are reported in the second row for each country fund.

\begin{tabular}{|c|c|c|c|c|c|c|c|c|c|c|c|c|c|c|c|}
\hline & & \multirow[t]{2}{*}{$a^{\text {Fund }}$} & \multicolumn{3}{|c|}{$\beta$} & \multicolumn{3}{|c|}{$\gamma$} & \multicolumn{3}{|c|}{$\phi$} & \multicolumn{3}{|c|}{$\psi$} & \multirow{2}{*}{$\begin{array}{c}R^{2} \\
(\%)\end{array}$} \\
\hline & & & $t-1$ & $t$ & $t+1$ & $t-1$ & $t$ & $t+1$ & $t-1$ & $t$ & $t+1$ & $t-1$ & $t$ & $t+1$ & \\
\hline \multicolumn{16}{|c|}{ Panel A: Daily Regression } \\
\hline \multirow[t]{2}{*}{ Brazil } & & 0.00 & -0.03 & 1.18 & -0.04 & -0.01 & 0.53 & 0.05 & -0.13 & 0.57 & -0.13 & -0.10 & -0.19 & -0.12 & \multirow[t]{2}{*}{43.39} \\
\hline & $t$-stat & $5.73 *$ & -0.35 & $17.28 *$ & -0.59 & -0.20 & $12.77^{*}$ & 1.67 & -1.38 & $6.14 *$ & -1.66 & -1.86 & $-2.85 *$ & $-2.34 \dagger$ & \\
\hline \multirow[t]{2}{*}{ Chile } & & 0.00 & 0.01 & 0.57 & -0.03 & 0.18 & 0.62 & 0.12 & -0.02 & 0.44 & -0.06 & -0.09 & -0.46 & -0.14 & \multirow[t]{2}{*}{34.16} \\
\hline & $t$-stat & $2.76^{*}$ & 0.25 & $11.85^{*}$ & -0.84 & $4.37 *$ & $13.77^{*}$ & $2.62 *$ & -0.30 & $6.11 *$ & -0.90 & -0.88 & $-4.50 *$ & -1.38 & \\
\hline \multirow[t]{2}{*}{ Mexico } & & 0.00 & -0.04 & 1.22 & 0.05 & 0.01 & 0.85 & 0.06 & -0.18 & 0.54 & -0.09 & -0.00 & -0.61 & -0.08 & \multirow[t]{2}{*}{57.10} \\
\hline & $t$-stat & $3.05 *$ & -1.02 & $22.34 *$ & 0.92 & 0.36 & $27.89^{*}$ & $2.27 \dagger$ & $-2.93 *$ & $7.47 *$ & -1.34 & -0.03 & $-9.29 *$ & -1.31 & \\
\hline \multirow[t]{2}{*}{ Thai } & & -0.00 & -0.05 & 0.97 & 0.08 & 0.08 & 0.39 & 0.15 & -0.14 & 0.51 & 0.09 & -0.14 & -0.12 & 0.02 & \multirow[t]{2}{*}{24.70} \\
\hline & $t$-stat & -0.97 & -0.50 & $9.92 *$ & 0.99 & $2.55 \dagger$ & $12.51^{*}$ & $4.42 *$ & -1.07 & $4.93 *$ & 0.90 & -1.13 & -1.17 & 0.16 & \\
\hline \multicolumn{16}{|c|}{ Panel B: Monthly Regression } \\
\hline \multirow[t]{2}{*}{ Brazil } & & 0.08 & 0.09 & 1.16 & -0.05 & 0.10 & 0.40 & 0.13 & $\begin{array}{l}-0.05 \\
\end{array}$ & 0.34 & -0.21 & -0.15 & -0.25 & -0.18 & \multirow[t]{2}{*}{63.18} \\
\hline & $t$-stat & $5.85^{*}$ & 0.79 & $5.66^{*}$ & -0.33 & $2.60 *$ & $8.32 *$ & $2.64 *$ & -0.16 & 1.05 & -0.80 & -1.60 & $-2.42 \dagger$ & $-2.52 \dagger$ & \\
\hline \multirow[t]{2}{*}{ Chile } & & 0.01 & 0.21 & 0.80 & -0.06 & -0.10 & 0.90 & 0.26 & 0.03 & 0.63 & -0.50 & -0.28 & -0.40 & 0.41 & \multirow[t]{2}{*}{65.57} \\
\hline & $t$-stat & 1.39 & 1.22 & $5.29 *$ & -0.35 & -1.79 & $8.01 *$ & $2.10 \dagger$ & 0.07 & 1.86 & -1.31 & -1.10 & -0.92 & 1.37 & \\
\hline \multirow[t]{2}{*}{ Mexico } & & 0.02 & 0.05 & 1.29 & -0.17 & 0.08 & 0.91 & 0.02 & -0.26 & 0.14 & -0.08 & 0.11 & -0.83 & 0.10 & \multirow[t]{2}{*}{75.97} \\
\hline & $t$-stat & $3.57 *$ & 0.36 & $9.09 *$ & -1.17 & 1.05 & $16.65^{*}$ & 0.21 & -1.30 & 0.58 & -0.38 & 0.93 & $-6.60 *$ & 1.58 & \\
\hline \multirow[t]{2}{*}{ Thai } & & -0.01 & 0.31 & 1.68 & 0.18 & 0.01 & 0.70 & 0.08 & 0.55 & -0.22 & -0.36 & 0.22 & -0.22 & -0.98 & \multirow[t]{2}{*}{61.52} \\
\hline & $t$-stat & -1.16 & 1.56 & $9.64 *$ & 0.79 & 0.10 & $8.87 *$ & 1.39 & 1.43 & -0.62 & -0.95 & 0.76 & -0.61 & $-2.20 \dagger$ & \\
\hline
\end{tabular}

*Significant at the $1 \%$ level; $\uparrow$ Significant at the $5 \%$ level 


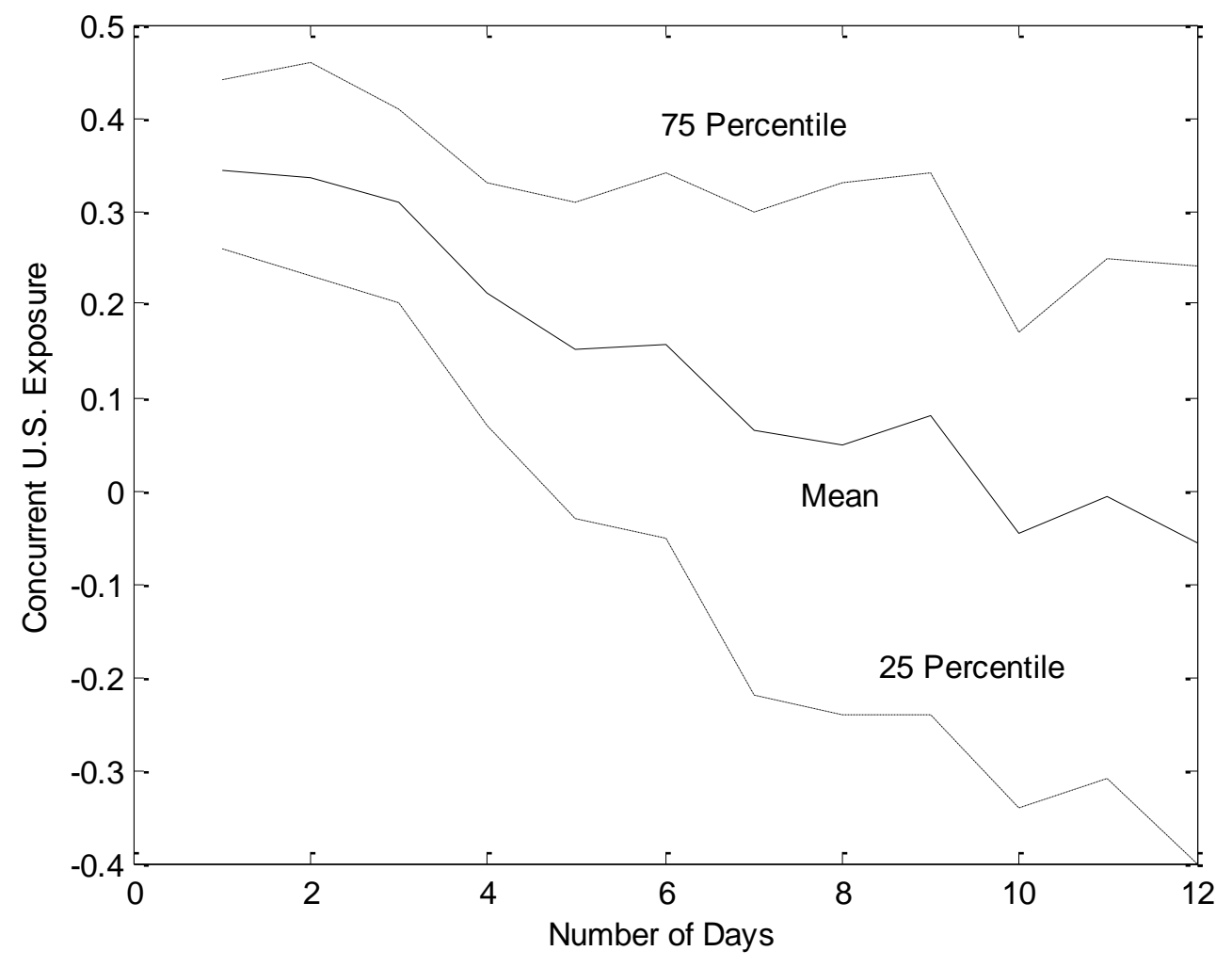

Figure 1: Concurrent U.S. Investor Sentiment Exposures

This figure depicts the mean, the 25 percentile, and the 75 percentile of concurrent U.S. investor sentiment exposures with daily returns aggregated over 1 to 12 days. 
International Business \& Economics Research Journal - January 2011

NOTES 